\title{
Active Fund Managers and Earnings Management at Portfolio Companies
}

\begin{abstract}
Purpose - In this paper, we examine the association between the types of mutual funds, i.e., active versus passive, and the level of earnings manipulation at the companies that comprise their stock portfolios.

Design/methodology/approach - We use Cremers and Petajisto (2009) classification of mutual funds by active share and tracking error volatility to differentiate between active and passive mutual funds. To assess the extent of earnings quality at portfolio companies, we measure accruals earnings management (AM) and real earnings management (RM).

Findings (mandatory) - We find that the portfolio firms held by active fund managers exhibit lower levels of earnings manipulation. The inverse relationship between earnings management and fund holdings is more pronounced at higher levels of active share selection among concentrated active fund managers.

Originality/value (mandatory) - This paper contributes to the understanding of how actively managed funds perform stock selection. Earnings manipulation leads to negative earnings quality that would inhibit stock performance over time. Active fund managers, who dynamically manage their exposures to systematic and stock-specific risks (in their attempt to outperform their benchmark index), target firms that manage earnings less to form part of their investment portfolios.
\end{abstract}

JEL Classification: G11; G23; M41

Keywords: Mutual Funds; Active versus Passive Funds; Earnings Management; Accruals Management; Real Activities Manipulations 


\section{Introduction}

The last three decades have witnessed a rapid rise in institutional investors' presence in the US stock market. They held $34 \%$ of all US stocks in the 1980s; an estimate in 2010 put that figure at $67 \%$ (Blume and Keim, 2012). The rise in their numbers has coincided with various improvements in both corporate governance and performance (see, for instance, Smith, 1996; Cornett et al., 2007; Guercio et al., 2008; Chen et al., 2010).

However, not all institutional investors are alike and have the same impact. Bushee (1998) separates institutional owners into three groups based on institutional investor's concentration in a firm and portfolio turnover rate, including transient, quasi-indexers and dedicated investors. Bushee (1998) suggests that dedicated investors and quasi-indexers have more incentives to monitor because they have larger and more concentrated holdings in the portfolio firms, while transient institutional investors have less incentive to monitor given their low ownership within the portfolio firms and their high portfolio turnover. There is still the longstanding debate of whether institutional investors improve corporate governance and performance through monitoring the firms versus voting with their feet (i.e., exit the firm). We consider that different types of institutional investors can impact firm performance variously. In this paper, we examine the association between the type of institutional investors, using a new measure, (i.e., active versus passive mutual funds) and the level of earnings manipulation at their portfolio companies.

Mutual funds can be of two types, i.e., active versus passive. Active funds engage in the active selection of shares with frequent trades. In contrast, passive mutual funds tend to track selective indices, for instance, the stock market indices, and trade less frequently. Cremers and Petajisto (2009) devise the measure of Active Share (AS) to complement the traditional measure 
of Tracking Error Volatility (TE) to assess the practice of active funds to manage their portfolios. "Active Share" refers to the portion of a fund's investment portfolio that is not replicating its benchmark stock index. To the extent that the fund's portfolio differs in the weightings of its benchmark index constituent stocks, then the value of Active Share is nonzero. Furthermore, the larger the difference in the weightings, the higher is the value of Active Share. "Tracking Error" measures the standard deviation of the difference between a fund's return and the return on the benchmark index. The larger the difference, the higher is the value of Tracking Error. Thus, low (high) values of Active Share and Tracking Error are associated with passive (active) investment funds.

Cremers and Petajisto (2009) find that high active share funds with better stock selection skills significantly outperform their benchmark indices. These funds also expose themselves to significant systematic risk by departing significantly from an index portfolio. In their quest to outperform benchmark portfolios, active fund managers engage in frequent portfolio adjustments based on systematic and stock-specific risks.

Active share funds trade frequently and have a high turnover rate which makes them similar to transient institutional investors described by Bushee (1998). The key question is how they select target firms to be included in their stock portfolios. In this paper, we examine the association between the activeness of the mutual funds and the earnings quality of their portfolio firms. ${ }^{1}$ It is well documented that higher earnings management is associated with lower earnings quality (see, for instance, Lo (2008)). As a result, shares of firms that are actively engaging in earnings management would exhibit inferior stock market performance, which would affect the performance of the funds that are holding these shares. We test the earnings management level at

\footnotetext{
${ }^{1} \mathrm{~A}$ portfolio firm is one whose stock is held by the fund.
} 
firms held by active and passive funds. To assess the extent of earnings quality ${ }^{2}$ at portfolio companies, we measure both accruals management (AM) and real activities manipulations (RM). To the extent that earnings management practices adversely affect the earnings quality of portfolio companies, which then decrease their ability to outperform benchmarks, active fund managers would eschew these companies.

We hypothesize an inverse relationship between fund ownership and earnings management. However, we go one step further and argue that the association between earnings management and fund shareholdings depends on the activeness of the fund's investment strategy. It makes sense for actively managed funds to avoid the shares of earnings manipulators. Conversely, passive funds hold shares in the exact proportion of benchmark indices. Thus, their investment decision cannot be based on earnings management at portfolio companies. Consider a firm that manages earnings and features in a benchmark index that is tracked by a passive fund. The latter would hold the stock of the earnings manipulator not because the firm is manipulating earnings but because the firm features in the benchmark index. As a result, we would expect to see little connection between the shareholdings of passive funds and the earnings management at their portfolio companies. To be precise, we argue that the inverse relationship between fund shareholdings and earnings management at their target companies is dependent upon the fund managers' level of activism. The notion of "activism" used in this paper does not refer to corporate governance activities provided by activist investors. In this paper, activism is based on the classification of active fund managers and the methodology of Petajisto (2013).

Next, portfolio companies can engage in several forms of earnings management. The literature has broadly classified earnings management into two types, i.e., accruals management

\footnotetext{
${ }^{2}$ High earnings management would lead to low earnings quality.
} 
(AM) and real earnings management (RM). AM considers the application of US generally accepted accounting principles (GAAP). It is argued that managers tend to use GAAP in a way that would reflect positively on the reported earnings figures. Thus, while AM contributes to project an earnings figure that differs from its true or fundamental level, yet AM has little real consequences on the firm's earnings generating capacity as no operations have been altered to manipulate the earnings figures.

Conversely, RM constitutes real transactions that affect firm operations. The object of such transactions is to boost short-term reported earnings figures, but they may come at the expense of long-term performance. Consider a firm that decides to reduce its discretionary expenditure on research and development. While the reduced spending will boost earnings in the short-term yet it will adversely affect the firm's ability to exploit innovations profitably in the long-run. How does this decomposition feature in the investment decision of fund managers? We argue that fund managers would be more concerned by RM at portfolio companies than AM since the adverse consequences of RM on earnings are real (unlike AM). Thus, we also test whether the funds' decision to eschew earnings manipulators is dependent on the earnings management type, i.e., AM versus RM.

In univariate analyzes, we break the sample of investment funds in ten deciles ranging from the least active fund to the most active one. We find the mean and median values of the real earnings management variables (RM) to be significantly lower in the decile containing the most active funds in comparison to the decile containing the least active ones. The results are not industry specific.

In the multivariate analyzes, we employ the Heckman two-stage self-selection correction model to examine the relationship between fund activeness and the extent of earnings 
manipulation at portfolio firms. In the first stage, we use a probit regression to estimate the likelihood a mutual fund selects a stock. The result of the probit regression shows that mutual funds are associated with portfolio firms with lower levels of real earnings management (RM). OLS regressions confirm the association between fund activeness and earnings manipulation at the portfolio firms while controlling for year fixed effects, sector fixed effects and mutual funds' self-selection of firms with better earnings quality. We also find that concentrated ownership of mutual funds is associated with lower levels of real earnings management at the portfolio firms. Our results suggest that funds with portfolios designed differently from stock market indices and benchmarks are inversely related to earnings-suspect firms.

To the best of our knowledge, besides Chung, Firth and Kim (2002), Koh (2003), Hadani, Goranova and Khan (2011), and Lin and Manowan (2012), there is limited research that examines the association between institutional investors' shareholdings and the extent of earnings management at their portfolio companies. ${ }^{3}$ Furthermore, almost none of the studies examine the relationship between real earnings management and institutional investors' activism in building their own unique portfolio. Such a study is important since it is documented that earnings management diminishes investor protection (Leuz, Nanda and Wysocki (2003)).

Our paper contributes to the literature by assessing the association between actively managed equity funds and their portfolio firms' earnings management. Our findings indicate portfolio firms held by funds with high active share and tracking error measures tend to have lower scores of earning management. Using real earnings management negatively affects future

\footnotetext{
${ }^{3}$ Koh (2003) examines the association between institutional ownership and Australian firms' aggressive earnings management strategies. He finds a positive association between transient short-term oriented institutional investors and earnings management. The association turns negative with long-term oriented institutional investors.
} 
firm value relative to the firm had they not engaged in real earnings management. Detecting and avoiding earnings management could explain how actively managed funds can outperform their benchmark indices. The rest of the paper proceeds as follows. Section 2 covers the literature review and the development of hypotheses. We describe the sample selection procedure and the data in Section 3. We present the methods and discuss the results in section 4. The last section concludes this paper.

\section{Literature Review and Development of Hypotheses}

Managers are under immense pressure to deliver earnings growth; especially those whose job is on the line (see Fudenberg and Tirole, 1995). Managerial incentives, by themselves, further encourage managers to seek higher earnings. Accounting methods that tend to lead to the highest reported earnings are therefore preferred at the expense of other methods that — though more appropriate—-would have resulted in a more conservative earnings figure. Accounting manipulations of these kinds lead to information asymmetry (Botosan (1997); Lang and Lundholm (1996); and, Chaterjee et al. (1999)), which affects shareholder's wealth. Chi and Gupta (2009) find an inverse association between overvaluation-induced income-increasing earnings management techniques and future abnormal stock returns.

Many studies find that managers use earnings management techniques opportunistically. Teoh, Welch, and Wong (1998) find that seasoned equity issuers raise reported earnings by altering discretionary accounting accruals. Rangan (1998) argues that the market appears to extrapolate earnings growth associated with discretionary accruals and hence overvalues issuing firms. The identification and impact of earnings management, therefore, continue to preoccupy academics, regulators and practitioners alike (Dechow and Skinner, 2000). 
Proficient external monitoring mitigates the practice of earnings management. For instance, Klein (2002) finds that the quality of the audit committee and the independence of the board adversely affect the firm's abnormal accruals. Xie, Davidson, and DaDalt (2003) find that discretionary current accruals reduce with the corporate and financial backgrounds of members of the board and audit committees, respectively. They also document an inverse relationship between discretionary accruals and the frequency with which the committees meet during a year. Sharma (2004) associates fewer frauds with a higher presence of institutional investors. Yu (2008) finds that firms followed by large numbers of financial analysts tend to manage earnings less.

Similar to the board and audit committees and other institutional investors, the actions of fund managers tend to influence a firm's propensity to manipulate earnings. Chung et al. (2002) find that the presence of institutional fund managers constrains executives' ability to use discretionary accruals to manipulate earnings. We extend that line of research by considering real activities manipulation techniques (RM) other than discretionary accruals. RM tends to be disguised as everyday operation decision and is damaging to a firm's value in the long run since it involves changes made to business operations (see Gunny (2005)).

We examine the association between the activism levels of fund managers and the extent of earnings management at their portfolio firms. To ascertain the activeness of a fund manager, we use two measures developed by Petajisto (2013), i.e., (i) Active Share and (ii) Tracking Error volatility. As previously mentioned, "Active Share" refers to the portion of a fund's investment portfolio that is not replicating its benchmark stock index. To the extent that the fund's portfolio differs in the weightings of its benchmark index constituent stocks, then the value of Active Share is nonzero. Furthermore, the larger the difference, the higher is the value of Active Share. 
"Tracking Error" measures the standard deviation of the difference between a fund's return and the return on a benchmark index. The larger the difference, the higher is the value of Tracking Error. Thus, low (high) values of Active Share and Tracking Error are associated with passive (active) investment funds.

The values of active share (AS) and tracking error (TE) are higher for active fund managers than passive ones. More specifically, active investors are heavily involved in stock selection (measured by AS) and factor timing (measured by TE) that yield different portfolio returns compared to benchmark ones (see also Grinold and Kahn (1995)). Given their willingness to chase returns, we hypothesize that active fund managers will avoid firms that manage earnings and significantly compromise their earnings quality. We use the measures of Petajisto (2013) to study the relationship between the composition of actively managed portfolios and earnings management at their portfolio companies.

Fund managers stand to lose significantly from the opportunistic behaviors of company executives that manipulate earnings. Especially, those who hold substantial shareholdings, they would not want the opportunistic actions of firms' executives to impact their wealth adversely.

H1: There exists an inverse association between fund ownership and earnings management.

However, the hypothesized relationship may not hold when the use of RM is beneficiary to all the parties. Managers can use RM for opportunistic reasons (e.g., Cohen and Zarowin (2010)) or to maximize shareholder value (e.g., Gunny (2010)). For instance, engaging in RM to avoid a debt covenant violation could end up benefiting the firm shareholders and, therefore, the funds owning the company shares. Managers though do not divulge their motives to manage 
earnings. The literature suggests that the use of earnings management is more detrimental to investors' wealth than the benefits it yields. As a result, while the possibility to use RM favorably exists, yet based on the methods used to measure earnings management in the current study it is unlikely that the practice of earnings management would yield benefits to the investors.

Do all funds select their portfolio firms equally? While the presence of fund managers has indeed served to enhance corporate governance, they tend not to be a homogenous group. Fund managers tend to differ by their investment goals. As explained above, there are active and passive fund managers, and there are further divisions within each category. Thus, it is essential to categorize fund managers properly into their relevant subgroups and then examine the effect of each on portfolio performance. Their management style will depend on the level of their shareholdings at portfolio firms, their investment horizons and the stability of their shareholdings, among other things. Along these lines, Koh (2007) differentiates between transient and long-term investors and argues that it is essential to consider the type of institutional investor in studies on earnings management. Burns, Kedia, and Lipson (2010) find that institutional investors with short investment horizons increase the likelihood and severity of financial misreporting. However, concentrated holdings by these investors produce the opposite effect. They argue that it is important to control for the nature of institutional monitoring.

To differentiate between active and inactive/passive fund managers, we follow the methodology of Petajisto (2013). We use the criteria of Active Share (AS) and Tracking Error (TE) to form four groups of managers that differ in their levels of activism and test the relationship between each cluster and the levels of earnings management at their portfolio companies. 
H2: The relationship between fund managers and earnings management at their portfolio companies is conditional upon their level of activism.

Ajinkya, Bhojraj, and Sengupta (2005) find that institutional investors favor firms that issue frequent and unbiased earnings forecasts. Hadani, Goranova, and Khan (2011) find an inverse relationship between earnings management and the stake of the largest institutional investor. These studies are based on discretionary accruals. Research on fund managers' attitude toward firms' real activities manipulations is scant, and our paper is an attempt to fill this gap. While the objectives of accrual-based earnings management (AM) and real activities manipulation (RM) are similar, their effects on business operations tend to differ. AM hardly affects the firm's operations and reverts over time. Under this method of earnings management, managers try to inflate reported earnings figure by merely changing accounting methods. For instance, a change in depreciation method or an inventory valuation method can provide an artificial and temporary boost to reported earnings.

Conversely, the effects on business operations of RM are more significant. They can take various forms including — but not limited to — overproduction and high inventory costs (which are then subtracted from the current year's costs and are carried forward), reductions in discretionary expenditure like research and development (R\&D), and selling, general and administrative (SG\&A) expenses. Investing less in R\&D can adversely affect the firm's competitive position in relation to its peers. Real activities manipulations tend to lead to abnormal levels of production costs and discretionary expenses. When compared to accruals management, they impede a firm's ability to generate future cash flows more severely (Graham et al. 2005; Roychowdhury 2006; Cohen et al. 2008; Cohen and Zarowin 2010; Zang 2012). 
In addition, changes in the regulatory environment are forcing managers to trade between the two methods. Following the Sarbanes-Oxley Act (SOX) of 2002, managers favor real activities manipulations over discretionary accruals since they are harder to detect (Cohen et al., 2008). Zang (2012) shows that managers trade-off between the two methods based on their relative costs and benefits. Managers favor real activities manipulations during the year by altering operations, finances, and investments. Accruals are adjusted at year end based on the outcomes of real activities manipulations. As a result, the two methods are not perfect substitutes, and the findings based on accruals management cannot be generalized to real activities manipulations. To the extent that fund managers expect real activities manipulations to be more damaging, they will monitor more closely changes in production costs and discretionary expenses at their portfolio firms.

\section{H3: The impact on fund ownership of discretionary accruals and real activities manipulations} differ.

Concentrated fund managers with substantial portfolio holdings at firms that manipulate earnings will incur considerable losses should they decide to divest their shareholdings. The sale of their sizeable shareholdings will cause the share price to depress and the revenue from the sale to plummet. Alternatively, efforts to shun mismanaged companies from their portfolios right from the start will lead to better outcomes. Fund managers will enhance their odds to generate positive excess returns by holding portfolio firms that generate earnings via regular business operations as opposed to manipulating the accounts. Bushee (1998) finds that high turnover and momentum trading (i.e., characteristics not associated with concentrated fund managers) by 
institutional investors significantly increase the likelihood that managers manage expenditure on $R \& D$ to reverse declines in earnings.

H4: Concentrated active fund managers exhibit the greatest aversion to earnings management at portfolio companies.

\section{Data}

Our data sources include Compustat, Thomson Financials CDA/Spectrum mutual fund holdings database and Professor Petajisto's Active Share database. ${ }^{4}$ Our sample period starts in 1990 and ends in 2009. We limit our sample to the year 2009 due to restrictions on the availability of active share data. We exclude firms with SIC codes 4900-4999 (i.e., utility firms) and 6000-6999 (i.e., financial firms) as they tend to be highly regulated.

The final sample consists of 14,643 firms, yielding 126,888 firm-year observations distributed as follows: 73,706 with data on institutional ownership and 53,182 without such data. Out of the 73,706 firm-year observations, 61,683 are held by all equity funds while the remainder 11,876 represent other types of holdings.

Table 1 reports the sample distribution by year (in Panel A) and by industry (in Panel B). In Panel A, we observe an increase in fund ownership over time. For instance, in 1990 there were more firm-year observations with no fund holdings, i.e., 2,650 versus 2,464 with fund holdings. By the final year of the sample period, though, the trend has reversed, i.e., there are more firmyear observations with fund holdings than those without $(3,606$ versus 1,812$)$.

\footnotetext{
${ }^{4} \mathrm{http}: / /$ www.petajisto.net/data.html
} 
We present the sample distribution by industry/sector in Panel B. We use the FamaFrench 12-sector classification codes for that purpose. ${ }^{5}$ The majority of the sample firms is in business equipment $(22.75 \%$ of the sample), health $(11.73 \%)$, manufacturing $(12.48 \%)$, and shops $(12.01 \%)$. Firm-year observations that are not categorized in any of the named sectors represent $17.95 \%$ of the sample.

\section{[INSERT TABLE 1 ABOUT HERE]}

In Table 2, we present sample descriptive statistics including SIZE (log of firm's total assets), MTB (the market-to-book ratio), ROA (return on assets), DEBT (the ratio of long-term liabilities-to-total assets), and MKTSH (the ratio of the firm's sales-to-total industry sales). Besides the overall sample (Panel A), we present the same statistics for various subsamples based on fund ownership type (Panels B to E). Firms that count mutual funds as capital suppliers (Panel C) are larger than firms without such fund ownership. They also have higher market-tobook ratios, ROAs, and market share; they have lower capital expenditure as a percentage of sales. We obtain similar findings when we partition the sample based on whether the mutual funds own the firms' equity (Panels D and E).

\section{[INSERT TABLE 2 ABOUT HERE]}

\section{Methodology}

\subsection{Active Funds}

To identify active funds, we use the variables of Active Share (AS) and Tracking Error (TE) as developed by Petajisto (2013). Active share (AS) is a proxy for a fund's ability to build a portfolio different from the benchmark index.

\footnotetext{
${ }^{5}$ http://mba.tuck.dartmouth.edu/pages/faculty/ken.french/Data_Library/det_12_ind_port.html
} 


$$
\text { Active Share }=\frac{1}{2} \sum_{i=1}^{N}\left|\omega_{\text {fund }, i}-\omega_{\text {index }, i}\right|
$$

where $\omega_{\text {fund,i } i}$ and $\omega_{\text {index }, i}$ are the portfolio weights of asset $i$ in the fund and in the benchmark index, respectively. Active share represents the proportion of a fund's portfolio that does not overlap with the benchmark index.

Tracking error (TE), also known as tracking error volatility, is defined as the standard deviation of the differences between a fund's returns $\left(R_{f u n d, t}\right)$ and its benchmark index returns over time $\left(R_{\text {index,t }}\right)$ as developed originally by Grinold and Kahn (1999). Tracking error volatility (TE) is the portion of a fund's volatility that is not explained by movements in the fund's benchmark index returns.

$$
\text { Tracking error }=\operatorname{Stdev}\left[R_{f u n d, t}-R_{\text {index }, t}\right]
$$

We obtain the data on tracking error (TE) and Active Share (AS) from Professor Petajisto's website. We divide the sample into quintiles based on the measures of TE and AS (also see Petajisto (2013)) and regroup the firms as follows: Diversified Inactive (DI), Concentrated Inactive (CI), Diversified Active (DA) and Concentrated Active (CA). DI represents the most passive funds while CA represents the most active funds. DI includes index funds. CI funds mimic only part of an index. DA funds follow their own sector and stock selection criteria. CA funds focus on particular sectors of an index but apply their own stock weightings. We create a neutral zone to have a clear separation between the groups since both active share and tracking error are continuous variables. Thus, the ordering of the four groups starts with the most active fund and ends with the most passive one as illustrated in the $5 \times 5$ grid below: 


\begin{tabular}{|c|c|c|c|c|c|c|c|}
\hline \multirow{2}{*}{$\begin{array}{l}\text { Active Share } \\
\text { Quintile }\end{array}$} & \multicolumn{5}{|c|}{ Tracking error quintile } & \multirow[b]{2}{*}{ Group } & \multirow[b]{2}{*}{ Label } \\
\hline & Low & 2 & 3 & 4 & High & & \\
\hline High & 3 & 3 & $\mathrm{~N}$ & 4 & 4 & 4 & Concentrated Active \\
\hline 4 & 3 & 3 & $\mathrm{~N}$ & 4 & 4 & 3 & Diversified Active \\
\hline 3 & $\mathrm{~N}$ & $\mathrm{~N}$ & $\mathrm{~N}$ & $\mathrm{~N}$ & $\mathrm{~N}$ & 2 & Concentrated Inactive \\
\hline 2 & 1 & 1 & $\mathrm{~N}$ & 2 & 2 & 1 & Diversified Inactive \\
\hline Low & 1 & 1 & $\mathrm{~N}$ & 2 & 2 & $\mathrm{~N}$ & Neutral Zone \\
\hline
\end{tabular}

\subsection{Earnings Management}

\subsubsection{Accrual-based earnings management (AM)}

Following previous research (Sloan 1996), we use discretionary accruals to proxy for accrual-based earnings management. Discretionary accrual refers to the difference between a firm's actual level of accruals and its expected normal level of accruals. We use the following modified Jones (1991) model to estimate the accruals:

$\frac{\text { Accruals }_{i, t}}{A_{i, t-1}}=\alpha_{0}+\alpha_{1}\left(\frac{1}{A_{i, t-1}}\right)+\alpha_{2}\left(\frac{\Delta \text { SALES }_{i, t}}{A_{i, t-1}}\right)+\alpha_{3}\left(\frac{P P E_{i, t}}{A_{i, t-1}}\right)+\varepsilon_{i, t}$

where Accruals $_{i, t}$ is the earnings before extraordinary items and discontinued operations minus the operating cash flows reported in the statement of cash flows of firm $i$ in year $t . A_{i, t-1}$ is the total asset of firm $i$ in year $t-1, \triangle S A L E S_{i, t}$ refers to the change in sales from the preceding year of firm $i$, and $P P E_{i, t}$ is the total gross value of property, plant and equipment of firm $i$ in year $t$. $\varepsilon_{i, t}$ is the residual that represents abnormal discretionary accruals, which is used as a proxy for accrual-based earnings management (AM) of firm i in year $t$.

Kothari et al. (2005) find that calculating discretionary accruals controlling for performance are a better-specified measure of discretionary accruals. Specifically, they estimate performance-adjusted discretionary accruals as the residual from the modified-Jones model and subtract off the residual from a firm in the same year and industry with the closest return-onassets. For robustness check, we calculate the variable DADIFF in the same way as Kothari et al. 
(2005). DADIFF is the difference between the modified Jones discretionary accruals for firm $\mathrm{i}$ in year $\mathrm{t}$ and the modified Jones discretionary accruals for the matched firm in year $\mathrm{t}$, following Kothari et al. (2005); each firm-year observation is matched with another firm from the same Fama and French 48-sector industry classification and year with the closest return on assets. Precisely, we match each firm-year with another firm that shares the same Fama-French 48sector classification code and is closest in the ratio of return on assets (ROA).

\subsubsection{Real Activities Manipulation (RM)}

Roychowdhury (2006) constructs three measures of real activities manipulation, i.e., abnormal cash flows from operations, abnormal discretionary expenses, and abnormal production costs. His measures are used by Cohen et al. (2008), Cohen and Zarowin (2010) and Zang (2012). We follow Zang (2012), who cautions against the use of abnormal cash flows, and instead finds abnormal discretionary expenses (RM_DISX) and production costs (RM_PROD) as less ambiguous measures of real activities manipulation.

To estimate the abnormal level of production costs, we use the following model:

$\frac{\operatorname{PROD}_{i, t}}{A_{i, t-1}}=\beta_{0}+\beta_{1}\left(\frac{1}{A_{i, t-1}}\right)+\beta_{2}\left(\frac{\text { sales }_{i, t}}{A_{i, t-1}}\right)+\beta_{3}\left(\frac{\Delta \text { Sales }_{i, t}}{A_{i, t-1}}\right)+\beta_{4}\left(\frac{\Delta \text { Sales }_{i, t-1}}{A_{i, t-1}}\right)+\mu_{i, t}$

where $P R O D_{i, t}$ is the sum of the cost of goods sold in year $t$ and the change in inventory from year $t-1$ to $t ; A_{i, t-1}$ is the total assets of firm $i$ in year $t-1 ;$ Sales $_{i, t}$ is the net sales of firm $i$ in year $t$; and $\Delta$ Sales $_{i, t}$ is the change in net sales of firm $i$ from year $t-1$ to $t$. The abnormal level of production cost (RM_PROD) is measured as the residuals from equation $(4)\left(\mu_{i, t}\right)$. The higher the value of the residual, the larger is the amount of abnormal production costs, and the greater is the increase in reported earnings through real activities manipulation.

We estimate the abnormal level of discretionary expenditure using the following model: 
$\frac{\operatorname{DISX}_{i, t}}{A_{i, t-1}}=\gamma_{0}+\gamma_{1}\left(\frac{1}{A_{i, t-1}}\right)+\gamma_{2}\left(\frac{\text { Sales }_{i, t-1}}{A_{i, t-1}}\right)+e_{i, t}$

where $D I S X_{t}$ is the discretionary expenditure (i.e., the sum of R\&D, advertising, and SG\&A expenditure) of firm $i$ in year $t ; A_{t-1}$ is the total assets of firm $i$ in year $t-1$; Sales $_{i, t}$ is the net sales of firm $i$ in year $t$. The abnormal level of discretionary expenditure (denoted as RM_DISX) is measured as the residuals from the regression $\left(e_{i, t}\right)$. The lower the value of the residuals, the lower the abnormal discretionary expenses, which suggest that firms cut down discretionary expenses excessively to inflate their earnings. We estimate Equations (3) to (5) cross-sectionally for each industry-year with at least 15 observations, where industry is defined following the Fama and French 48-sector industry classification. ${ }^{6}$ We report the regression results of equations (3) through (5) in Appendix 1.

We follow Cohen et al. (2008) and Zang (2012) to aggregate the two individual measures of real activities manipulation into one measure of total real earnings management (RM). The higher the value of this aggregate measure, i.e., RM, the more likely the firm is engaged in real activities manipulation (Zang, 2012).

$$
R M_{-} P R O D_{i, t}+R M_{-} D I S X_{i, t}=R M_{i, t}
$$

\subsubsection{Funds' holdings and earnings management}

A possible endogeneity issue might arise in that mutual funds may very well select firms with certain levels of earnings management in the first place. To address the self-selection bias, we employ the Heckman's two-stage self-selection approach. We first estimate the probability of a firm selected by a mutual fund and then calculate the inverse Mills ratio from this estimated

\footnotetext{
${ }^{6} \mathrm{http}: / / \mathrm{mba}$.tuck.dartmouth.edu/pages/faculty/ken.french/Data_Library/det_48_ind_port.html

${ }^{7}$ We multiply RM_DISX by -1 such that the higher the value of RM_DISX, the larger the amount of discretionary expenditure cut by the firm to inflate reported earnings. This transformation allows us to express the signs of RM_DISX and RM_PROD in the same manner (i.e., positive values suggest real activities manipulations) and to be able to add both to obtain the composite score of RM (similar to Cohen et al. (2008) and Zang (2012)).
} 
probability. In the second stage, we control for the inverse Mills ratio, in addition to year fixed effects and sector fixed effects, in our regressions of earnings management on mutual fund ownership.

Similar to Elyasiani et al. (2010), we estimate the probability a firm is part of a mutual fund's portfolio using the following probit regression:

$$
\begin{aligned}
& \text { INSTHOLD }_{i, t}=k_{0}+k_{1} \text { RM_PROD }_{i, t-1}+k_{2} R_{-} M_{-} D I S X_{i, t-1}+k_{3} R M_{i, t-1}+ \\
& k_{4} \text { AM }_{i, t-1}+k_{5} \text { DADIFF }_{i, t-1}+k_{6} \text { SIZE }_{i, t-1}+k_{7} \text { RISK }_{i, t-1}+k_{8} \text { LNSHARES }_{i, t-1}+ \\
& k_{9} \text { TURNOVER } \\
& i, t-1
\end{aligned}
$$

where, INSTHOLD $D_{i, t}$ is a dummy variable representing the presence of a mutual fund as an owner. $R M_{-} P R O D_{t-1}, R M_{-} D I S X_{t-1}, R M_{t-1}, A M_{t-1}$ and $D A D I F F_{t-1}$ are the abnormal production costs, abnormal discretional expenses, total real earnings management, discretionary accruals and performance-adjusted discretionary accruals management in the preceding year. $S I Z E_{i, t-l}$ is the natural $\log$ of total assets of the firm in the preceding year; $R I S K_{i, t-1}$ is the idiosyncratic risk of the firm in the preceding year. Idiosyncratic risk is measured as the annualized standard deviation of the residuals from the regressions of the stock daily returns based on the FamaFrench's three-factor model. ${ }^{8}$ LNSHARES $_{i, t-1}$ is the lagged natural log of the number of shares outstanding of the firm. TURNOVER ${ }_{i, t-1}$ is the average of the ratios of daily traded shares-to-total number of shares outstanding in the preceding year. We obtain the predicted probability from equation (7), and calculate the inverse Mills ratio and include this variable in the second stage regression to control for self-selection bias.

\footnotetext{
${ }^{8}$ http://mba.tuck.dartmouth.edu/pages/faculty/ken.french/data_library.html
} 
Zang (2012) explains that managers consider the tradeoffs between the costs and benefits of real activities manipulation before engaging in such activities. To be consistent with the prior literature, we follow her model specification and the choice of the explanatory variables in our regressions of firm earnings management as follows:

$$
\begin{aligned}
& R M_{i, t}=k_{0}+k_{1} I N S T_{i, t-1}+k_{2} I N V S M I L L S_{i, t}+k_{3} \operatorname{MKTSH}_{i, t-1}+k_{4} Z S C O R E_{i, t-1} \\
& +k_{5} T_{A X} X_{i, t-1}+k_{6} A_{U D I T O R} R_{i, t-1}+k_{7} N O A_{i, t-1}+k_{8} O P E R C Y C L E_{i, t-1} \\
& +k_{9} L N M K C A P_{i, t}+k_{10} D E B T_{i, t}+k_{11} M K B K_{i, t}+k_{12} R O A_{i, t}+u_{i, t} \\
& A M_{i, t}=k_{0}+k_{1} I_{N S T} T_{i, t-1}+k_{2} U N E X P R M_{i, t}+k_{3} I N V S M I L L S_{i, t}+k_{4} M_{K T S H} H_{i, t-1} \\
& +k_{5} \operatorname{ZSCORE}_{i, t-1}+k_{6} \mathrm{TAX}_{i, t-1}+k_{7} \operatorname{AUDITOR}_{i, t-1}+k_{8} N O A_{i, t-1} \\
& +k_{9} \text { OPERCYCLE } E_{i, t-1}+k_{10} L N M K C A P_{i, t}+k_{11} D E B T_{i, t}+k_{12} M K B K_{i, t} \\
& +k_{13} R O A_{i, t}+u_{i, t}
\end{aligned}
$$

where $R M_{i, t}$ represents the total real earnings management and $A M$ represents the accruals-based earnings management. $I N S T_{i, t-1}$ captures the various measures of mutual fund ownership. We test the effects of six alternative measures of mutual fund ownership one at a time as follows: INSTHOLD $D_{i, t}$ is a dummy variable representing the presence of a fund owner in the firm ownership structure; $E Q T H O L D_{i, t}$ is a dummy variable representing the equity ownership of a mutual fund; SUMDISHR $R_{i, t}$ SUMCISHR $i, t, S U M D A S H R_{i, t}$ and $S U M C A S H R_{i, t}$ represent the oneyear lagged values of the percentages of shares held by Diversified Inactive (DI), Concentrated Inactive (CI), Diversified Active (DA) and Concentrated Active (CA) fund investors, respectively. We expect the percentage of shares held by the respective fund managers to be inversely related to the variables capturing earnings management. We control for year fixed 
effects, industry fixed effects and correct the standard errors for the firm-level clustering effects in addition to the inverse Mills ratio to control for the self-selection issue.

With regard to the other independent variables, Zang (2012) finds an inverse association between the use of real activities manipulation and accruals-based earnings management and explains that managers tend to favor real activities manipulation during the year and then adjust the accruals at the end of the year if needed. Following Zang (2012), we obtain the residuals from equation (8) as a proxy for the unexpected level of real activities manipulation and include this new variable, i.e., UNEXPRM, in equation (9). MKTSH is the ratio of a company's sales to the total sales of all the firms in the same industry based on the Fama-French (1997) 48-sector industry classification; $Z S C O R E_{t}$ is a modified version of Altman's Z-score (Altman 1968, 2000) - a proxy for financial condition. Higher values for ZSCORE indicate a healthier financial condition and a lower cost associated with real activities manipulation. The ZSCORE is computed as follows:

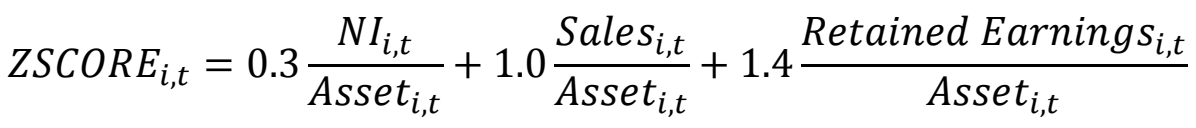

$$
\begin{aligned}
& +1.2 \frac{{\text { Working } \text { Capital }_{i, t}}_{\text {Asset }_{i, t}}}{\text {. }} \\
& +0.6 \frac{(\text { Stock Price } \times \text { Shares Outstanding })_{i, t}}{\text { Total Liabilities }_{i, t}}
\end{aligned}
$$

$N O A_{t-1}$ represents net operating assets at the beginning of the year and serves as a proxy for the extent of accrual management in previous periods. $N O A_{t-1}$ is calculated as:

$$
\begin{aligned}
& {\text { Shareholders' } \text { Equity }_{t-1}-\text { Cash and Marketable Securities }}_{t-1}+\text { Total Debt }_{t-1} \\
& \text { Sales }_{t-1}
\end{aligned}
$$

$C Y C L E_{t-1}$ is computed as the days receivable plus the days inventory less the days payable at the beginning of the year; $L N M K C A P_{i, t}$ represents the natural logarithm of market capitalization; 
$D E B T_{i, t}$ is the ratio of long term liabilities-to-market capitalization; and $R O A_{i, t}$ represents the return on assets.

\section{Results}

\subsection{Univariate analyses}

We provide summary statistics of the earnings management variables in Panel A of Table 3. In Panel B, we provide the correlation matrix between the earnings management variables and the fund ownership variables. While the real earnings management variables (RM_PROD, RM_DISX, and RM) are negatively correlated with the fund ownership variables, the discretionary accruals management variable is positively correlated. The opposite correlations between the two types of earnings management (i.e., RM versus discretionary accruals) and fund ownership are consistent with Zang's (2012) argument that real earnings management and discretionary accruals management are negatively correlated to each other. Managers tend to weigh the costs and benefits of engaging in these two forms of earnings management and accordingly engage in one form versus the other.

\section{[INSERT TABLE 3 ABOUT HERE]}

In Panel C, we compare and contrast the earnings management levels between firms with and without fund ownership. Firms with fund ownership are associated with significantly less real earnings management than firms without fund ownership; however, these firms are associated with more discretionary accruals management. A similar pattern is observed when we compare firms with equity fund ownership and firms with non-equity fund ownership (in Panel D). There seems to exist an aversion against real earnings management in the portfolio choices of fund managers. 
To the extent that real earnings management adversely affects firms' operating cash flows and profitability, fund managers (concentrated active (CA) fund managers, in particular, since they are heavily involved in stock selections and factor timings) are less likely to hold the shares of common stock of these firms in their investment portfolios. Thus, we expect to find portfolio companies of the most active funds to exhibit the lowest scores of earnings management. To test this hypothesis, we divide the subsample of CA funds into deciles. We rank the CA funds from the least active (Decile 1) to the most active (Decile 10). We compare the mean and median scores of the earnings management variables between the first and the tenth deciles and present our findings in Table 4.

\section{[INSERT TABLE 4 ABOUT HERE]}

The use of real activity manipulation could lead to unsold inventory, little product development, and a depleted resource base, which would dampen active fund managers' interests in such companies. Thus, we expect to find a strong inverse relationship between the measures of real earnings management and the levels of funds' activism. Indeed, results from Panel A of Table 4 suggest that the mean and median values of the real earnings management variables (i.e., RM_PROD, RM_DISX, and RM) are all significantly lower in the tenth decile of CA funds (i.e., the most active ones) than the first decile of CA funds (i.e., the least active ones). Conversely, there exists no statistically significant difference between the values of AM and DADIFF (i.e., the two measures of earnings management via discretionary accruals) between the first and tenth deciles of CA funds. To the extent that RM is more detrimental to shareholders' wealth than AM, then the active fund managers are expected to exhibit a greater aversion toward RM than AM.

We test whether the findings based on real activities manipulations are industry driven. We present the results by industry sector in Panel B of Table 4. We test whether the mean and 
median RM values are significantly lower in the tenth decile (i.e., the most active funds) compared to the first decile (i.e., the least active funds) in each sector. We use the Fama-French 12-sector classification codes to classify the firms into industries. The results are consistent with the ones documented in Panel A for all sectors except one. Our findings are robust across industry sectors.

\subsection{Multiple Regressions}

In this section, we use multiple regression techniques to study the relationship between funds' holdings and the levels of earnings management at their portfolio firms. We report the results of the probit regression in Table 5. Consistent with our expectation, mutual funds tend to avoid firms with higher real earnings management (e.g., higher abnormal production costs, lower abnormal discretionary expenses ${ }^{9}$, and higher total real earnings management). Unlike the RM variables, the sign of the coefficient of the AM variable is opposite, and that of DADIFF is statistically insignificant. Thus, mutual funds are more apprehensive about the damaging effects of RM than AM.

\section{[INSERT TABLE 5 ABOUT HERE]}

\subsubsection{Real earnings management and active mutual fund ownership}

In Table 6, we report the regressions of real earnings management $(R M)$ on the active mutual fund ownership measures. The coefficient of the dummy variable INSTHOLD is negatively related to $R M$, which is consistent with the univariate findings documented above.

\footnotetext{
${ }^{9}$ Notice that since we have multiplied the RM_DISX by -1 in the construction of the variables, the negative coefficient on the RM_DISX variable as reported in Table 5 should be interpreted as higher earnings management via discretionary expenditure (e.g. cutting down discretionary expenditure)
} 
However, the relationship is conditional on the type of the mutual fund. Real earnings management is significantly lower in the presence of the most active group of funds (SUMCASHR). Although the coefficients representing the other mutual funds (i.e., Diversified Inactive (SUMDISHR), Concentrated Inactive (SUMCISHR), Diversified Active (SUMDASHR)) are negative yet their $t$-stats are not statistically significant. Thus, the existence of the inverse association between fund ownership and earnings management at portfolio companies is more robust amongst the most active of these funds.

\section{[INSERT TABLE 6 ABOUT HERE]}

Since our sample period includes the years of the most recent financial crisis in the U.S. (2007-2009), we present the results separately for the non-crisis period (1990-2006) and the crisis period (2007-2009) in Tables 7A and 7B, respectively. The crisis period coincided with a severe stock market downturn that brought significant losses to mutual funds and forced many of them to cut their losses. Indeed, the findings in Table 7 suggests that there was a shift in the strength of the association between funds' investments and portfolio companies' earnings management from prior to during the crisis. The coefficients of the INSTHOLD and SUMCASHR variables are negative and statistically significant in the non-crisis period but not during the crisis period. The financial crisis confounds fund managers' ability to trace real activities manipulations as other systematic forces are dragging firm's performance. It should not be the case under ordinary circumstances, and fund managers are more effective at identifying earnings management during the non-crisis periods.

[INSERT TABLES 7A AND 7B ABOUT HERE]

\subsubsection{Accruals-based earnings management and active mutual fund ownership}


In Table 8, we regress discretionary accruals (AM) on the various measures of fund ownership. The coefficient representing the most active mutual funds, i.e., SUMCASHR, is negative and statistically significant at the 0.01 level. The same applies to SUMDISHR and SUMCISHR, which represent the percentage of shares held by Diversified Inactive and Concentrated Inactive mutual funds, respectively. However, we should note that the equity ownership of SUMDISHR and SUMCISHR is determined by other factors besides fund managers' skills. For instance, many of them track stock indices passively and infrequently trade to realign their portfolio shareholdings with their benchmark indices.

\section{[INSERT TABLE 8 ABOUT HERE]}

To isolate the effects of the 2007-2009 financial crisis, we run the regression during the non-crisis period and present our findings in Table 9A. The findings mirror those of Table 8, i.e., ownership of the most active mutual funds continues to be inversely related to the level of earnings management at portfolio firms. We present the findings during the financial crisis period in Table 9B and find the aversion to discretionary accruals management from active mutual funds to persist. The coefficients of SUMDASHR and SUMCASHR are both negative and statistically significant. They represent ownership by Diversified Active and Concentrated Active mutual funds, respectively.

\section{[INSERT TABLES 9A AND 9B ABOUT HERE]}

For the most part, the findings from the multiple regressions suggest that funds that build their portfolios differently from indexes and benchmarks display an aversion to earnings-suspect firms. ${ }^{10}$

\footnotetext{
${ }^{10}$ We examine regression results for the pre- and post-SOX periods separately (not tabulated), and the results are similar for both periods. Thus, the fund managers' approach to earnings management at portfolio companies stayed the same from pre- to post-SOX. The relationship is
} 


\section{Conclusion}

Active share, AS, (Petajisto, 2013) is an additional portfolio metric that complements the traditional measure of tracking error (TE), and provides a robust means to explain how active fund managers generate excess returns. We examine the choices of portfolio companies by the fund managers with high AS and TE, i.e., active fund managers who attempt to outperform their benchmarks by performing their own stock selections and factor timings.

In their quest to outperform benchmark indices, active mutual fund managers increase their exposure to both systematic and idiosyncratic company-specific risks. Our study looks at one aspect of the idiosyncratic risk, i.e., exposure to earnings manipulation at the portfolio firm level. To assess the extent of earnings manipulations at portfolio companies, we examine both accruals management (AM) and real activities manipulations (RM). When compared to AM, RM impedes a firm's ability to generate future cash flows in the long-term more severely.

We find lower scores of earnings management at companies comprising the portfolios of the active fund managers. Results based on RM are more robust than AM. Active fund managers are more apprehensive of the adverse consequences of RM and are keen to avoid them. This inverse association becomes more pronounced as the level of activism increases amongst concentrated active fund managers. Detecting and avoiding earnings management could be one of the reasons why actively managed funds outperform the benchmark.

The degree to which earnings management influences mutual funds' investment behavior has significant implications for the stability of the U.S. stock market. Based on our findings that

also unaffected by the shift in companies' focus from discretionary accruals to real activities manipulations post-SOX. 
earnings management at portfolio companies serves as a potential instrument to guide funds' investment decisions, future research would examine how these investment preferences exert price pressure (if any) on the stock of the portfolio companies. It would also help to ascertain whether the investment preferences of fund managers with respect to earnings management help to render the stock market more or less efficient. 


\section{References:}

Ajinkya, B., Bhojraj, S. \& Sengupta, P. (2005), "Directors, institutional investors and the properties of management earnings forecasts", Journal of Accounting Research, Vol. 43, pp. 343-376.

Altman, E. I. (1968), "Financial ratios, discriminant analysis and the prediction of corporate bankruptcy", The journal of finance, Vol. 23(4), pp. 589-609.

Altman, E. I. (2000), "Predicting financial distress of companies: revisiting the Z-score and ZETA models", Stern School of Business, New York University, pp. 9-12.

Blume, M. E., \& Keim, D. B. (2012), "Institutional investors and stock market liquidity: trends and relationships", Available at SSRN 2147757.

Botosan, C. A. (2000), "Evidence that greater disclosure lowers the cost of equity capital", Journal of Applied Corporate Finance, Vol. 12(4), pp. 60-69.

Burns, N., Kedia, S. \& Lipson, M. (2010), "Institutional ownership and monitoring: Evidence from financial misreporting", Journal of Corporate Finance, Vol. 16, pp. 443-455.

Bushee, B. J. (1998). The influence of institutional investors on myopic R\&D investment behavior. Accounting Review, 305-333.

Chatterjee, S., Lubatkin, M.H. \& Schulze W.S. (1999), "Toward a strategic theory of risk premium: Moving beyond CAPM", Academy of Management Review, Vol. 24, pp. 556-567.

Chen, X., Harford, J. \& Li, K. (2007), “Monitoring: Which institutions matter?”, Journal of Financial Economics, Vol. 86, pp. 279-305.

Chi, J. \& Gupta, M. (2009), “Overvaluation and earnings management”, Journal of Banking \& Finance, Vol. 33, pp. 1652-1663.

Chung, R., Firth, M. \& Kim, J. (2002), “Institutional monitoring and opportunistic earnings management", Journal of Corporate Finance, Vol. 8, pp. 29-48.

Cohen, D. A., \& Zarowin, P. (2010), “Accrual-based and real earnings management activities around seasoned equity offerings", Journal of Accounting and Economics, Vol. 50(1), pp. 2-19.

Cohen, D., Dey, A. \& Lys, D. (2008), "Real and accrual-based earnings management in the preand post- Sarbanes-Oxley period", The Accounting Review, Vol. 83, pp. 757-787.

Cornett, M. M., Marcus, A. J., Saunders, A., \& Tehranian, H. (2007), “The impact of institutional ownership on corporate operating performance", Journal of Banking \& Finance, Vol. 31(6), pp. 1771-1794. 
Cremers, K. M., \& Petajisto, A. (2009), "How active is your fund manager? A new measure that predicts performance", Review of Financial Studies, Vol. 22(9), pp. 3329-3365.

Cremers, Martijn and Petajisto, Antti and Zitzewitz, Eric, Should Benchmark Indices Have Alpha?

Revisiting Performance Evaluation (January 21, 2010). EFA 2009 Bergen Meetings Paper; AFA

2010 Atlanta Meetings Paper. Available at SSRN: https://ssrn.com/abstract $=1108856$ or

http://dx.doi.org/10.2139/ssrn.1108856

Dechow, P.M. \& Skinner, D.J. (2000), "Earnings management: reconciling the views of accounting academics, practitioners and regulators", Accounting Horizon, Vol. 14, pp. 235-250.

Del Guercio, D., Seery, L., \& Woidtke, T. (2008), "Do boards pay attention when institutional investor activists "just vote no"?”, Journal of Financial Economics, Vol. 90(1), pp. 84-103.

Elyasiani, E., D. Jia and Mao, C. (2010), "Institutional ownership stability and the cost of debt", Journal of Financial Markets, Vol. 13(4), pp. 475-500.

Fama, E. F., \& French, K. R. (1997), "Industry costs of equity", Journal of financial economics, Vol. 43(2), pp. 153-193.

Fudenberg, D., \& Tirole, J. (1995), "A theory of income and dividend smoothing based on incumbency rents", Journal of Political economy, Vol. 103(1), pp. 75-93.

Graham, J. R., Harvey, C. R., \& Rajgopal, S. (2005), “The economic implications of corporate financial reporting", Journal of accounting and economics, Vol. 40(1), pp. 3-73.

Grinold, R. \& Kahn, R. (1995), Active Portfolio Management, New York: McGraw-Hill, pp. 221-224.

Gunny, K. A. (2005), "What are the consequences of real earnings management?”, working paper, Haas School of Business, University of California, Berkeley. Accessed at: http://citeseerx.ist.psu.edu/viewdoc/download?doi=10.1.1.463.841\&rep=rep1\&type=pdf

Hadani, M., Goranova, M. \& Khan. (2011), "Institutional investors, shareholder activism, and earnings management”, Journal of Business Research, Vol. 64, pp. 1352-1360.

Jones, J. J. (1991), "Earnings management during import relief investigations", Journal of accounting research, Vol. 29(2), pp.193-228.

Klein, A., (2002), "Audit committee, board of directors characteristics, and earnings management", Journal of Accounting and Economics, Vol. 33, pp. 375-400.

Koh, P., (2007) "Institutional investor type, earnings management and benchmark beaters", Journal of Accounting and Public Policy, Vol. 26, pp. 267-299. 
Lang, M. H., \& Lundholm, R. J. (1996), "Corporate disclosure policy and analyst behavior", Accounting review, Vol. 71(4), pp. 467-492.

Lin, L., \& Manowan, P. (2012), "Institutional ownership composition and earnings management", Review of Pacific Basin Financial Markets and Policies, Vol. 15(04), pp. 1250022.

Lo, K. (2008), "Earnings management and earnings quality", Journal of Accounting and Economics, Vol. 45(2), pp. 350-357.

Petajisto, A. (2013), “Active share and mutual fund performance", Financial Analysts Journal, Vol. 69(4), pp. 73-93.

Rangan, S., (1998), "Earnings management and the performance of seasoned equity offerings", Journal of Financial Economics, Vol. 50, pp. 101-122.

Roychowdhury, S. (2006), "Earnings management through real activities manipulation”, Journal of accounting and economics, Vol. 42(3), pp. 335-370.

Sharma, V. D. (2004), "Board of director characteristics, institutional ownership, and fraud: Evidence from Australia", Auditing: A Journal of Practice \& Theory, Vol. 23(2), pp. 105-117.

Sloan, R. (1996), "Do Stock Prices Fully Reflect Information in Accruals and Cash Flows about Future Earnings?(Digest Summary)”, Accounting review, Vol. 71(3), pp. 289-315.

Smith, M. P. (1996), "Shareholder activism by institutional investors: Evidence from CalPERS", The Journal of Finance, Vol. 51(1), pp. 227-252.

Teoh, S.H., Welch, I. \& Wong, T.J. (1997), "Earnings management and the post-issue underperformance of seasoned equity offerings", Journal of Financial Economics, Vol. 50, pp. 63-69.

Xie, B., Davidson, W.N. \& DaDalt, P. (2003), "Earnings management and corporate governance: The role of board and the audit committee", Journal of Corporate Finance, Vol. 9, pp. 295-316.

Yu, F., (2008), “Analyst coverage and earnings management”, Journal of Financial Economics, Vol. 88, pp. 245-271.

Zang, A. Y. (2011), "Evidence on the trade-off between real activities manipulation and accrualbased earnings management", The Accounting Review, Vol. 87(2), pp. 675-703.

Zellner, A., \& Theil, H. (1962), "Three-stage least squares: simultaneous estimation of simultaneous equations", Econometrica: Journal of the Econometric Society, Vol. 30(1), pp. 5478. 
Table 1 - Sample Distribution

\begin{tabular}{|c|c|c|c|c|c|c|c|c|c|c|}
\hline \multicolumn{11}{|c|}{ Panel A-Sample Distribution by Year } \\
\hline \multirow[b]{2}{*}{ Year } & \multicolumn{2}{|c|}{ Whole Sample } & \multicolumn{2}{|c|}{ Without Fund Holding } & \multicolumn{2}{|c|}{ With Fund Holding } & \multicolumn{2}{|c|}{ Without Fund Equity Holding } & \multicolumn{2}{|c|}{ With Fund Equity Holding } \\
\hline & Frequency & Percent & Frequency & Percent & Frequency & Percent & Frequency & Percent & Frequency & Percent \\
\hline 1990 & 5,114 & 4.03 & 2,650 & 4.98 & 2,464 & 3.34 & 639 & 5.38 & 1,825 & 2.95 \\
\hline 1991 & 5,209 & 4.11 & 2,658 & 5 & 2,551 & 3.46 & 650 & 5.47 & 1,901 & 3.07 \\
\hline 1992 & 5,432 & 4.28 & 2,665 & 5.01 & 2,767 & 3.75 & 733 & 6.17 & 2,034 & 3.29 \\
\hline 1993 & 5,836 & 4.6 & 2,688 & 5.05 & 3,148 & 4.27 & 603 & 5.08 & 2,545 & 4.12 \\
\hline 1994 & 6,067 & 4.78 & 2,697 & 5.07 & 3,370 & 4.57 & 550 & 4.63 & 2,820 & 4.56 \\
\hline 1995 & 6,455 & 5.09 & 2,873 & 5.4 & 3,582 & 4.86 & 506 & 4.26 & 3,076 & 4.97 \\
\hline 1996 & 7,296 & 5.75 & 3,315 & 6.23 & 3,981 & 5.4 & 557 & 4.69 & 3,424 & 5.54 \\
\hline 1997 & 7,372 & 5.81 & 3,174 & 5.97 & 4,198 & 5.7 & 554 & 4.66 & 3,644 & 5.89 \\
\hline 1998 & 7,089 & 5.59 & 2,918 & 5.49 & 4,171 & 5.66 & 622 & 5.24 & 3,549 & 5.74 \\
\hline 1999 & 7,651 & 6.03 & 3,365 & 6.33 & 4,286 & 5.81 & 700 & 5.89 & 3,586 & 5.8 \\
\hline 2000 & 7,508 & 5.92 & 3,175 & 5.97 & 4,333 & 5.88 & 804 & 6.77 & 3,529 & 5.71 \\
\hline 2001 & 7,142 & 5.63 & 3,108 & 5.84 & 4,034 & 5.47 & 698 & 5.88 & 3,336 & 5.4 \\
\hline 2002 & 6,783 & 5.35 & 2,812 & 5.29 & 3,971 & 5.39 & 641 & 5.4 & 3,330 & 5.39 \\
\hline 2003 & 6,524 & 5.14 & 2,707 & 5.09 & 3,817 & 5.18 & 534 & 4.5 & 3,283 & 5.31 \\
\hline 2004 & 6,424 & 5.06 & 2,520 & 4.74 & 3,904 & 5.3 & 490 & 4.13 & 3,414 & 5.52 \\
\hline 2006 & 6,065 & 4.78 & 2,127 & 4 & 3,938 & 5.34 & 517 & 4.35 & 3,421 & 5.53 \\
\hline 2007 & 5,753 & 4.53 & 1,841 & 3.46 & 3,912 & 5.31 & 526 & 4.43 & 3,386 & 5.48 \\
\hline 2008 & 5,537 & 4.36 & 1,770 & 3.33 & 3,767 & 5.11 & 504 & 4.24 & 3,263 & 5.28 \\
\hline 2009 & 5,418 & 4.27 & 1,812 & 3.41 & 3,606 & 4.89 & 517 & 4.35 & 3,089 & 5 \\
\hline Total & 126,888 & 100.01 & 53,182 & 100 & 73,706 & 100 & 11,876 & 100 & 61,830 & 100 \\
\hline
\end{tabular}

Panel B - Sample Distribution by Industry

\begin{tabular}{|c|c|c|c|c|c|c|c|c|c|c|}
\hline \multirow[b]{2}{*}{ Industry } & \multicolumn{2}{|c|}{ Whole Sample } & \multicolumn{2}{|c|}{ Without Fund Holding } & \multicolumn{2}{|c|}{ With Fund Holding } & \multicolumn{2}{|c|}{ Without Fund Equity Holding } & \multicolumn{2}{|c|}{ With Fund Equity Holding } \\
\hline & Frequency & Percent & Frequency & Percent & Frequency & Percent & Frequency & Percent & Frequency & Percent \\
\hline BUSEQ & 28,870 & 22.75 & 11,547 & 21.71 & 17,323 & 23.5 & 2,615 & 22.02 & 14,708 & 23.79 \\
\hline CHEMS & 3,660 & 2.88 & 1,364 & 2.56 & 2,296 & 3.12 & 399 & 3.36 & 1,897 & 3.07 \\
\hline DURBL & 3,948 & 3.11 & 1,529 & 2.88 & 2,419 & 3.28 & 385 & 3.24 & 2,034 & 3.29 \\
\hline ENRGY & 7,837 & 6.18 & 3,751 & 7.05 & 4,086 & 5.54 & 906 & 7.63 & 3,180 & 5.14 \\
\hline HLTH & 14,888 & 11.73 & 5,930 & 11.15 & 8,958 & 12.15 & 1,315 & 11.07 & 7,643 & 12.36 \\
\hline MANUF & 15,835 & 12.48 & 5,542 & 10.42 & 10,293 & 13.96 & 1,523 & 12.82 & 8,770 & 14.18 \\
\hline NODUR & 8,182 & 6.45 & 3,267 & 6.14 & 4,915 & 6.67 & 757 & 6.37 & 4,158 & 6.72 \\
\hline SHOPS & 15,235 & 12.01 & 6,407 & 12.05 & 8,828 & 11.98 & 1,189 & 10.01 & 7,639 & 12.35 \\
\hline TELCM & 6,032 & 4.75 & 3,065 & 5.76 & 2,967 & 4.03 & 551 & 4.64 & 2,416 & 3.91 \\
\hline OTHER & 22,401 & 17.65 & 10,780 & 20.27 & 11,621 & 15.77 & 2,236 & 18.83 & 9,385 & 15.18 \\
\hline
\end{tabular}

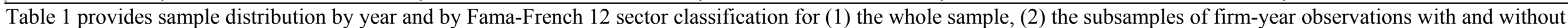

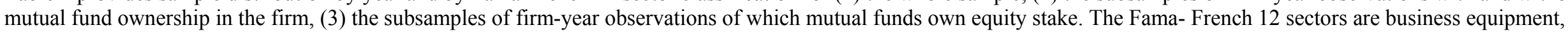
chemicals, durables, energy, health, manufacturing, non-durables, shops, telecom, and other. 


\begin{tabular}{|c|c|c|c|c|}
\hline \multicolumn{5}{|c|}{$\begin{array}{l}\text { Table } 2 \text { - Firm Charactel } \\
\text { Panel } A \text { - Whole Sample }\end{array}$} \\
\hline Variable & $\mathrm{N}$ & Mean & Median & Std Dev \\
\hline$\overline{S I Z E}$ & 126,888 & 4.773 & 4.727 & 2.457 \\
\hline$M T B$ & 115,326 & 2.731 & 1.820 & 7.092 \\
\hline$R O A$ & 126,888 & -0.199 & 0.018 & 1.160 \\
\hline$D E B T$ & 126,888 & 0.198 & 0.040 & 0.705 \\
\hline MKTSH & 126,888 & 0.032 & 0.002 & 0.079 \\
\hline \multicolumn{5}{|c|}{ Panel B - Firms without Fund Holding } \\
\hline Variable & $\mathrm{N}$ & Mean & Median & Std Dev \\
\hline SIZE & 53,182 & 4.055 & 3.905 & 2.628 \\
\hline$M T B$ & 42,477 & 2.590 & 1.628 & 8.528 \\
\hline$R O A$ & 53,182 & -0.356 & -0.008 & 1.592 \\
\hline$D E B T$ & 53,182 & 0.242 & 0.039 & 0.830 \\
\hline MKTSH & 53,182 & 0.025 & 0.001 & 0.071 \\
\hline \multicolumn{5}{|c|}{ Panel C - Firms with Fund Holding } \\
\hline Variable & $\mathrm{N}$ & Mean & Median & Std Dev \\
\hline SIZE & 73,706 & 5.291 & 5.146 & 2.185 \\
\hline$M T B$ & 72,849 & 2.814 & 1.912 & 6.099 \\
\hline$R O A$ & 73,706 & -0.086 & 0.030 & 0.676 \\
\hline$D E B T$ & 73,706 & 0.165 & 0.041 & 0.597 \\
\hline MKTSH & 73,706 & 0.037 & 0.004 & 0.085 \\
\hline \multicolumn{5}{|c|}{ Panel D - Firms without Fund Equity Holding } \\
\hline Variable & $\mathrm{N}$ & Mean & Median & Std Dev \\
\hline SIZE & 11,876 & 3.515 & 3.034 & 2.370 \\
\hline$M T B$ & 11,501 & 2.391 & 1.446 & 8.312 \\
\hline$R O A$ & 11,876 & -0.343 & -0.010 & 1.344 \\
\hline$D E B T$ & 11,876 & 0.265 & 0.035 & 0.920 \\
\hline MKTSH & 11,876 & 0.017 & 0.000 & 0.059 \\
\hline \multicolumn{5}{|c|}{ Panel E - Firms with Fund Equity Holding } \\
\hline Variable & $\mathrm{N}$ & Mean & Median & Std Dev \\
\hline SIZE & 61,830 & 5.632 & 5.427 & 1.972 \\
\hline$M T B$ & 61,348 & 2.893 & 1.995 & 5.584 \\
\hline$R O A$ & 61,830 & -0.036 & 0.035 & 0.428 \\
\hline$D E B T$ & 61,830 & 0.146 & 0.042 & 0.510 \\
\hline MKTSH & 61,830 & 0.040 & 0.005 & 0.088 \\
\hline
\end{tabular}

This table presents the characteristics of the whole sample in Panel A and for each subsample in Panels B through E. Size (log of total assets), MTB (market-to-book ratio), MKTSH (ratio of firms' sales to industry total sales), ROA (net income scaled by total assets), and $D E B T$ (total liabilities scaled by total assets). 
Table 3 - Comparisons of Earnings Management Measures between the Subsamples Classified by Fund Ownership

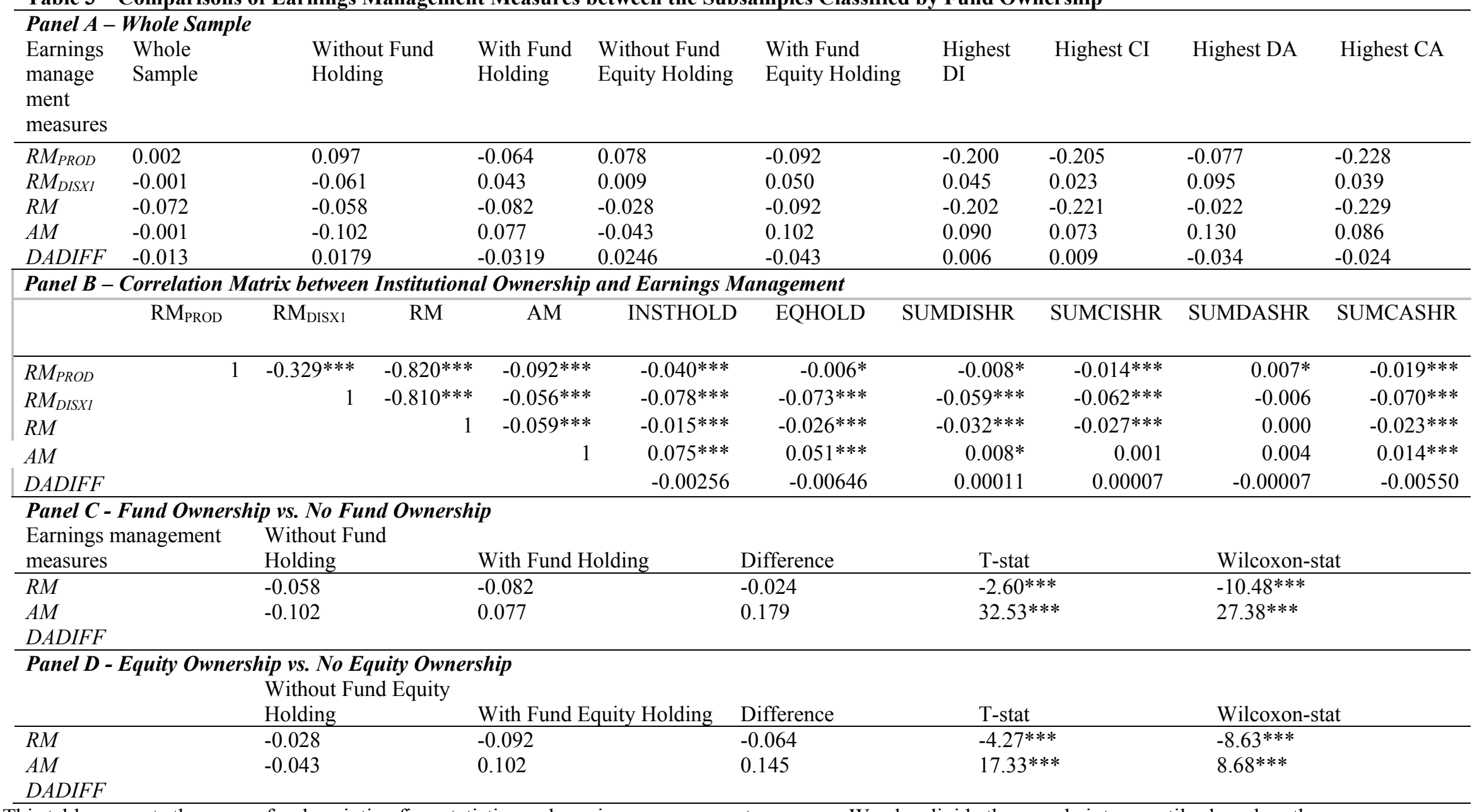

This table presents the means for descriptive firm statistics and earnings management measures. We also divide the sample into quantiles based on the measures of Active Share and Tracking Error, and regroup the firms as follows: Diversified Inactive (DI), Concentrated Inactive (CI), Diversified Active (DA) and Concentrated Active (CA). The ranking starts with DI representing the most passive funds and ends with CA representing the most active funds. SUMDISHR (Percent of firm's outstanding shares owned by diversified inactive institutional investors), SUMCISHR (Percent of firm's outstanding shares owned by concentrated inactive institutional investors), SUMDASH (Percent of firm's outstanding shares owned by diversified active institutional investors), and SUMCASHR (Percent of firm's outstanding shares owned by concentrated active institutional investors). RM_PROD represents the abnormal level of production cost. $R M D I S X$ represents the abnormal level of discretionary expenditure. $R M$ represents total real earnings management. $A M$ represents discretionary accruals management. DADIFF is the difference between the modified Jones discretionary accruals for firm i in year $\mathrm{t}$ and the modified Jones discretionary accruals for 
the matched firm in year t, following Kothari et al. (2005); each firm-year observation is matched with another firm from the same Fama and French 48-sector industry classification and year with the closest return on assets. We perform the t-test and the Wilcoxon tests for differences in means and medians, respectively. $* * *, * *$, and * indicate significance at $1 \%$ percent, $5 \%$, and $10 \%$ levels, respectively. 


\begin{tabular}{|c|c|c|c|c|c|c|c|c|c|c|c|c|c|c|c|c|}
\hline \multicolumn{17}{|c|}{ Panel A - Whole Sample } \\
\hline \multicolumn{17}{|c|}{ Rank of Percent Active Deciles } \\
\hline Variable & 1 & 2 & 3 & 4 & \multicolumn{2}{|l|}{5} & \multicolumn{2}{|l|}{6} & \multicolumn{2}{|l|}{7} & 8 & 9 & 10 & 1-10 DIFF & $t$-stat & Wilcoxon \\
\hline$R M_{P R O D}$ & 0.050 & -0.022 & -0.049 & -0.01 & -0.0 & & -0 . & 01 & -0 & 098 & -0.104 & -0.116 & -0.228 & 0.278 & $13.32 * * *$ & $14.39 * * *$ \\
\hline$R M_{D I S X I}$ & 0.071 & 0.097 & 0.068 & 0.052 & 0.02 & & 0.0 & & 0.0 & 34 & 0.057 & 0.073 & 0.039 & 0.032 & $3.87 * * *$ & $7.82 * * *$ \\
\hline$R M$ & 0.008 & -0.013 & -0.060 & -0.01 & -0.1 & & -0 . & 27 & -0 & 101 & -0.076 & -0.069 & -0.229 & 0.236 & $8.11 * * *$ & $10.06^{* * *}$ \\
\hline$A M$ & 0.042 & 0.065 & 0.092 & 0.113 & 0.11 & & 0.1 & & 0.1 & 13 & 0.128 & 0.124 & 0.086 & -0.044 & -1.47 & -0.20 \\
\hline$D A D I F F$ & -0.053 & -0.042 & -0.025 & -0.01 & 0.02 & & -0 . & 54 & -0. & 085 & -0.061 & -0.073 & -0.024 & 0.028 & 0.53 & 0.27 \\
\hline \multicolumn{17}{|c|}{ Panel B - RM Measure by Concentrated Active Ownership Deciles \& Industry } \\
\hline Sector & Mean & 1 & 2 & 3 & 4 & 5 & & 6 & & 7 & 8 & 9 & 10 & 1-10 DIFF & $t$-stat & Wilcoxon \\
\hline 1 & -0.041 & -0.045 & -0.275 & -0.307 & -0.025 & & 106 & -0.20 & & -0.144 & -0.164 & 0.101 & -0.425 & 0.380 & 1.06 & 1.32 \\
\hline 2 & 0.133 & -0.076 & 0.201 & 0.117 & 0.309 & & 89 & 0.14 & & 0.176 & 0.464 & 0.379 & 0.260 & -0.336 & -0.43 & -0.80 \\
\hline 3 & -0.014 & 0.265 & 0.200 & 0.032 & 0.016 & & 178 & -0.11 & & -0.139 & -0.127 & -0.149 & -0.299 & 0.564 & $6.47 * * *$ & $6.64 * * *$ \\
\hline 4 & -0.055 & -0.103 & 0.134 & -0.065 & 0.023 & & 061 & -0.05 & & -0.038 & 0.090 & 0.103 & 0.068 & -0.171 & -0.85 & -1.25 \\
\hline 5 & -0.296 & -0.117 & -0.355 & -0.744 & -0.398 & & 452 & -0.42 & & -0.237 & -0.205 & -0.105 & -0.059 & -0.057 & $-1.73^{*}$ & -0.91 \\
\hline 6 & -0.168 & -0.058 & -0.082 & -0.058 & -0.066 & & 191 & -0.17 & & -0.136 & -0.227 & -0.171 & -0.384 & 0.326 & $6.02 * * *$ & $8.18 * * *$ \\
\hline 7 & -0.112 & -0.187 & -0.360 & -0.333 & -0.114 & & 016 & -0.07 & & -0.046 & 0.076 & -0.115 & -0.124 & -0.064 & $-1.89^{*}$ & $-2.85 * *$ \\
\hline 9 & -0.055 & 0.120 & -0.001 & -0.025 & -0.065 & & 034 & -0.10 & & -0.155 & -0.088 & -0.214 & -0.288 & 0.408 & $3.41 * * *$ & $5.63 * * *$ \\
\hline 10 & -0.249 & -0.272 & -0.159 & -0.266 & -0.255 & & 312 & -0.36 & & -0.252 & -0.169 & -0.138 & -0.181 & -0.091 & -0.34 & -0.10 \\
\hline 12 & 0.087 & 0.197 & 0.234 & 0.311 & 0.331 & 0.2 & 54 & 0.16 & & 0.146 & 0.174 & 0.173 & 0.002 & 0.195 & $3.52 * * *$ & $2.79 * * *$ \\
\hline
\end{tabular}

This table presents the mean earnings management measures by concentration active ownership deciles for the whole sample in Panel A and for each sector in

Panel B.The firm industry distribution is based upon the Fama-French 12 sectors coded as follows: 1. Non-Durable, 2. Durable, 3. Manufacturing, 4. Energy, 5.

Chemical, 6. Bus Equipment, 7. Telecommunications, 9. Shops, 10. Health, and 12. Other. RM represents real earnings management. AM represents

discretionary accruals management. DADIFF is the difference between the modified Jones discretionary accruals for firm $\mathrm{i}$ in year $\mathrm{t}$ and the modified Jones

discretionary accruals for the matched firm in year $t$, following Kothari et al. (2005); each firm-year observation is matched with another firm from the same

Fama and French 48-sector industry classification and year with the closest return on assets. We perform the t-test and the Wilcoxon tests for differences in

means and medians, respectively. ${ }^{* *},{ }^{* *}$, and $*$ indicate significance at $1 \%$ percent, $5 \%$, and $10 \%$ levels, respectively. 
Table 5 - Probit Regressions of Mutual Fund Ownership

\begin{tabular}{|c|c|c|c|c|c|c|}
\hline Variables & Model 1 & Model 2 & Model 3 & Model 4 & Model 5 & Model 6 \\
\hline Constant & $\begin{array}{l}-0.315 \\
(-3.653 * * *)\end{array}$ & $\begin{array}{l}-0.280 \\
(-3.169 * * *)\end{array}$ & $\begin{array}{l}-0.297 \\
(-3.197 * * *)\end{array}$ & $\begin{array}{l}-0.292 \\
(-3.101 * * *)\end{array}$ & $\begin{array}{l}-0.292 \\
(-3.275 * * *)\end{array}$ & $\begin{array}{l}-0.101 \\
(-2.774 * * *)\end{array}$ \\
\hline$R M_{-} P R O D_{i, t-1}$ & & $\begin{array}{l}-0.177 \\
(-8.873 * * *)\end{array}$ & & & & \\
\hline$R M_{-} D I S X_{i, t-1}$ & & & $\begin{array}{l}-0.137 \\
(-4.528 * * *)\end{array}$ & & & \\
\hline$R M_{i, t-1}$ & & & & $\begin{array}{l}-0.145 \\
(-4.547 * * *)\end{array}$ & & \\
\hline$A M_{i, t-1}$ & & & & & $\begin{array}{l}0.039 \\
\left(2.555^{* *}\right)\end{array}$ & \\
\hline$D A D I F F_{i, t-1}$ & & & & & & $\begin{array}{l}0.010 \\
(0.744)\end{array}$ \\
\hline$S I Z E_{i, t-1}$ & 1.198 & 1.173 & 1.253 & 1.248 & 1.175 & $\begin{array}{l}1.159 \\
\left(32.585^{* * *}\right.\end{array}$ \\
\hline & $\left(35.706^{* * *}\right)$ & $(32.471 * * *)$ & $\left(33.879^{* * *}\right)$ & $\left(32.93^{* * *}\right)$ & $(33.61 * * *)$ & ) \\
\hline $\operatorname{RISK}_{i, t-1}$ & $\begin{array}{l}-0.264 \\
\left(-2.455^{* *}\right)\end{array}$ & $\begin{array}{l}-0.269 \\
\left(-1.687^{*}\right)\end{array}$ & $\begin{array}{l}-0.251 \\
(-2.104 * *)\end{array}$ & $\begin{array}{l}-0.268 \\
\left(-1.713^{*}\right)\end{array}$ & $\begin{array}{l}-0.232 \\
\left(-2.189^{* *}\right)\end{array}$ & $\begin{array}{l}-0.171 \\
(-2.176 * *)\end{array}$ \\
\hline LNSHARES $_{i, t-1}$ & $\begin{array}{l}-0.672 \\
(-19.61 * * *)\end{array}$ & $\begin{array}{l}-0.690 \\
(-18.74 * * *)\end{array}$ & $\begin{array}{l}-0.739 \\
(-19.47 * * *)\end{array}$ & $\begin{array}{l}-0.753 \\
\left(-19.16^{* * *}\right)\end{array}$ & $\begin{array}{l}-0.671 \\
(-18.88 * * *)\end{array}$ & $\begin{array}{l}-0.693 \\
\left(-18.98^{* * *}\right)\end{array}$ \\
\hline TURNOVER $_{i, t-1}$ & $\begin{array}{l}-0.227 \\
(-2.637 * * *)\end{array}$ & $\begin{array}{l}-0.269 \\
\left(-3.206^{* * *}\right)\end{array}$ & $\begin{array}{l}-0.294 \\
(-3.643 * * *)\end{array}$ & $\begin{array}{l}-0.317 \\
(-3.914 * * *)\end{array}$ & $\begin{array}{l}-0.237 \\
\left(-2.738^{* * *}\right)\end{array}$ & $\begin{array}{l}-0.123 \\
(-6.561 * * *)\end{array}$ \\
\hline Pseudo R-squared & 0.087 & 0.086 & 0.090 & 0.089 & 0.084 & 0.0817 \\
\hline Chi squared & $1746.00^{* * *}$ & $1600.00^{* * *}$ & $1597.00^{* * *}$ & $1508.00 * * *$ & $1673.00 * * *$ & $1559.00^{* * *}$ \\
\hline Year fixed effect & Yes & Yes & Yes & Yes & Yes & Yes \\
\hline Sector fixed effect & Yes & Yes & Yes & Yes & Yes & Yes \\
\hline Clustered std err by firms & Yes & Yes & Yes & Yes & Yes & Yes \\
\hline classification & $69.61 \%$ & $70.11 \%$ & $70.62 \%$ & $70.98 \%$ & $69.76 \%$ & $69.85 \%$ \\
\hline Observations & 106,406 & 97,841 & 93,876 & 88,616 & 103,683 & 84,407 \\
\hline
\end{tabular}

This table reports the probit regression results of mutual fund ownership. The dependent variable is the indicator variable for whether a firm has mutual fund owners or not. $R M_{-} P R O D_{i, t-1}$ represents the abnormal level of production cost. $R M_{-} D I S X_{i, t-1}$ represents the abnormal level of discretionary expenditure. $R M_{i, t-1}$ represents total real earnings management. $A M_{i, t-1}$ represents discretionary accruals management. $D A D I F F$ is the difference between the modified Jones discretionary accruals for firm $i$ in year $t$ and the modified Jones discretionary accruals for the matched firm in year $t$, following Kothari et al. (2005); each firm-year observation is matched with another firm from the same Fama-French 48 industry classification and year with the closest return on assets. SIZE $E_{i, t-1}$ is the natural log of total assets of the firm in the preceding year; $R I S K_{i, t-I}$ is the idiosyncratic risk of firm in the preceding year. Idiosyncratic risk is measured as the annualized standard deviation of the residuals from the regressions of the firm daily returns on the Fama-French's 3 factors. LNSHARES $S_{i, t-1}$ is the lagged natural log of the number of shares outstanding of the firm. TURNOVER $R_{i, t-1}$ is the average of the ratios of daily traded shares to shares outstanding in the preceding year. $* * *, * *$, and $*$ indicate significance at $1 \%$ percent, $5 \%$, and $10 \%$ levels, respectively. 
Table 6 - OLS Regressions of Total Real Earnings Management on Institutional Ownership

\begin{tabular}{|c|c|c|c|c|c|c|}
\hline Variables & Model 1 & Model 2 & Model 3 & Model 4 & Model 5 & Model 6 \\
\hline Constant & $\begin{array}{l}0.516 \\
(3.866 * * *)\end{array}$ & $\begin{array}{l}0.701 \\
(6.310 * * *)\end{array}$ & $\begin{array}{l}0.523 \\
(3.929 * * *)\end{array}$ & $\begin{array}{l}0.520 \\
(3.890 * * *)\end{array}$ & $\begin{array}{l}0.536 \\
(4.017 * * *)\end{array}$ & $\begin{array}{l}0.520 \\
(3.910 * * *)\end{array}$ \\
\hline$I_{N S T H O L D} D_{i, t-1}$ & $\begin{array}{l}-0.067 \\
(-2.451 * *)\end{array}$ & & & & & \\
\hline$E Q T H O L D_{i, t-1}$ & & $\begin{array}{l}-0.069 \\
\left(-1.784^{*}\right)\end{array}$ & & & & \\
\hline$S_{U M D I S H R}{ }_{i, t-I}$ & & & $\begin{array}{l}-0.975 \\
(-0.900)\end{array}$ & & & \\
\hline SUMCISHR $_{i, t-1}$ & & & & $\begin{array}{l}-1.009 \\
(-0.568)\end{array}$ & & \\
\hline$S U M D A S H R_{i, t-1}$ & & & & & $\begin{array}{l}-1.070 \\
(-0.650)\end{array}$ & \\
\hline$S U M C A S H R_{i, t-1}$ & & & & & & $\begin{array}{l}-0.434 \\
(-2.487 * *)\end{array}$ \\
\hline $\operatorname{INVMILLS}_{i, t}$ & $\begin{array}{l}10.592 \\
(6.035 * * *)\end{array}$ & $\begin{array}{l}12.087 \\
(6.412 * * *)\end{array}$ & $\begin{array}{l}11.685 \\
(6.139 * * *)\end{array}$ & $\begin{array}{l}11.754 \\
\left(6.183^{* * *}\right)\end{array}$ & $\begin{array}{l}11.734 \\
(6.197 * * *)\end{array}$ & $\begin{array}{l}10.734 \\
(5.688 * * *)\end{array}$ \\
\hline$M K T S H_{i t-1}$ & $\begin{array}{l}-0.000 \\
(-0.220)\end{array}$ & $\begin{array}{l}-0.000 \\
(-2.691 * * *)\end{array}$ & $\begin{array}{l}-0.004 \\
(-2.164 * *)\end{array}$ & $\begin{array}{l}-0.004 \\
(-2.163 * *)\end{array}$ & $\begin{array}{l}-0.004 \\
(-2.162 * *)\end{array}$ & $\begin{array}{l}-0.004 \\
\left(-2.166^{* *}\right)\end{array}$ \\
\hline$Z S C O R E_{i t-1}$ & $\begin{array}{l}0.678 \\
(4.978 * * *)\end{array}$ & $\begin{array}{l}0.543 \\
(3.681 * * *)\end{array}$ & $\begin{array}{l}0.690 \\
(4.437 * * *)\end{array}$ & $\begin{array}{l}0.689 \\
(4.434 * * *)\end{array}$ & $\begin{array}{l}0.687 \\
(4.413 * * *)\end{array}$ & $\begin{array}{l}0.753 \\
(4.776 * * *)\end{array}$ \\
\hline$T A X_{i t-1}$ & $\begin{array}{l}-0.028 \\
(-0.808)\end{array}$ & $\begin{array}{l}-0.026 \\
(-0.648)\end{array}$ & $\begin{array}{l}-0.029 \\
(-0.632)\end{array}$ & $\begin{array}{l}-0.029 \\
(-0.620)\end{array}$ & $\begin{array}{l}-0.029 \\
(-0.637)\end{array}$ & $\begin{array}{l}-0.018 \\
(-0.403)\end{array}$ \\
\hline$A U D I T O R_{i t-1}$ & $\begin{array}{l}0.000 \\
(2.466 * *)\end{array}$ & $\begin{array}{l}0.000 \\
(1.641)\end{array}$ & $\begin{array}{l}0.000 \\
(2.561 * *)\end{array}$ & $\begin{array}{l}0.000 \\
(2.567 * *)\end{array}$ & $\begin{array}{l}0.000 \\
(2.581 * * *)\end{array}$ & $\begin{array}{l}0.000 \\
(2.682 * * *)\end{array}$ \\
\hline$N O A_{i t-1}$ & $\begin{array}{l}0.000 \\
(2.119 * *)\end{array}$ & $\begin{array}{l}0.000 \\
(1.318)\end{array}$ & $\begin{array}{l}0.000 \\
(0.707)\end{array}$ & $\begin{array}{l}0.000 \\
(0.705)\end{array}$ & $\begin{array}{l}0.000 \\
(0.698)\end{array}$ & $\begin{array}{l}0.000 \\
(0.679)\end{array}$ \\
\hline OPERCYCLE $E_{i t-1}$ & $\begin{array}{l}-0.094 \\
(-12.22 * * *)\end{array}$ & $\begin{array}{l}-0.113 \\
(-12.45 * * *)\end{array}$ & $\begin{array}{l}-0.107 \\
(-10.71 * * *)\end{array}$ & $\begin{array}{l}-0.109 \\
(-10.73 * * *)\end{array}$ & $\begin{array}{l}-0.110 \\
(-10.92 * * *)\end{array}$ & $\begin{array}{l}-0.108 \\
(-10.72 * * *)\end{array}$ \\
\hline$L N M K C A P_{i t}$ & $\begin{array}{l}0.000 \\
(0.077)\end{array}$ & $\begin{array}{l}-0.006 \\
(-3.231 * * *)\end{array}$ & $\begin{array}{l}0.025 \\
(0.631)\end{array}$ & $\begin{array}{l}0.025 \\
(0.616)\end{array}$ & $\begin{array}{l}0.024 \\
(0.594)\end{array}$ & $\begin{array}{l}0.019 \\
(0.486)\end{array}$ \\
\hline$D E B T_{i t}$ & $\begin{array}{l}-0.000 \\
(-0.818)\end{array}$ & $\begin{array}{l}-0.000 \\
(-0.425)\end{array}$ & $\begin{array}{l}0.000 \\
(0.359)\end{array}$ & $\begin{array}{l}0.000 \\
(0.358)\end{array}$ & $\begin{array}{l}0.000 \\
(0.358)\end{array}$ & $\begin{array}{l}0.000 \\
(0.363)\end{array}$ \\
\hline$M K B K_{i t}$ & $\begin{array}{l}0.104 \\
(6.856 * * *)\end{array}$ & $\begin{array}{l}0.077 \\
(3.132 * * *)\end{array}$ & $\begin{array}{l}0.023 \\
(0.765)\end{array}$ & $\begin{array}{l}0.024 \\
(0.793)\end{array}$ & $\begin{array}{l}0.025 \\
(0.814)\end{array}$ & $\begin{array}{l}0.023 \\
(0.748)\end{array}$ \\
\hline$R O A_{i t}$ & $\begin{array}{l}-0.624 \\
(-4.866 * * *)\end{array}$ & $\begin{array}{l}-0.887 \\
(-8.468 * * *)\end{array}$ & $\begin{array}{l}-0.755 \\
(-5.120 * * *)\end{array}$ & $\begin{array}{l}-0.748 \\
(-5.097 * * *)\end{array}$ & $\begin{array}{l}-0.750 \\
(-5.121 * * *)\end{array}$ & $\begin{array}{l}-0.776 \\
(-5.245 * * *)\end{array}$ \\
\hline F-statistics & $10.82 * * *$ & $10.23 * * *$ & $8.70 * * *$ & $8.68 * * *$ & $8.67 * * *$ & $8.96 * * *$ \\
\hline Adj. R-squared & 0.030 & 0.033 & 0.032 & 0.032 & 0.032 & 0.032 \\
\hline Year fixed effect & Yes & Yes & Yes & Yes & Yes & Yes \\
\hline Sector fixed effect & Yes & Yes & Yes & Yes & Yes & Yes \\
\hline Clustered std err by firms & Yes & Yes & Yes & Yes & Yes & Yes \\
\hline Observations & 83,324 & 55,871 & 48,425 & 48,425 & 48,425 & 48,425 \\
\hline
\end{tabular}

This table reports the OLS regressions of total real activities manipulation. The dependent variable is the level of total real earnings management of firm $i$ in year $t$, which is the sum of abnormal production cost and the abnormal discretionary expenditures. INST captures the various measures of mutual fund involvement in the firm. We employ 6 alternative measures of mutual fund ownership. INSTHOLD is a dummy variable representing the presence of a fund owner in the firm ownership structure. EQTHOLD is a dummy variable representing the equity ownership of a mutual fund. SUMDISHR, SUMCISHR, SUMDASHR and SUMCASHR represent the one-year lagged values of the percentages of shares held by Diversified Inactive (DI), Concentrated Inactive (CI), Diversified Active (DA) and Concentrated Active (CA) fund investors, respectively. The choice of the remaining control variables are as per Zang (2012). MKTSH is the ratio of a company's sales to the total sales of all the firms in the same industry based on the Fama-French (1997) 48-sector industry classification; ZSCORE $t$ is a modified version of Altman's Z-score (Altman 1968, 2000) — a proxy for financial condition. $N O A_{t-1}$ represents net operating assets at the beginning of 
the year and serves as a proxy for the extent of accrual management in previous periods. $N C Y C L E_{t-1}$ is computed as the days receivable plus the days inventory less the days payable at the beginning of the year:LNMKCAP $P_{t}$ represents the natural logarithm of market capitalization; $D E B T_{t}$ is the ratio of long term liabilities-to-market capitalization; and $R O A_{t}$ represents the return on assets. We control for year fixed effects, industry fixed effects and correct the standard errors for the firm-level clustering effects. $* * *, * *$, and * indicate significance at $1 \%$ percent, $5 \%$, and $10 \%$ levels, respectively. 


\begin{tabular}{|c|c|c|c|c|c|c|}
\hline Variables & Model 1 & Model 2 & Model 3 & Model 4 & Model 5 & Model 6 \\
\hline Constant & $\begin{array}{l}0.720 \\
(7.244 * * *)\end{array}$ & $\begin{array}{l}0.694 \\
(5.880 * * *)\end{array}$ & $\begin{array}{l}0.488 \\
(3.467 * * *)\end{array}$ & $\begin{array}{l}0.492 \\
(3.467 * * *)\end{array}$ & $\begin{array}{l}0.493 \\
(3.507 * * *)\end{array}$ & $\begin{array}{l}0.479 \\
(3.412 * * *)\end{array}$ \\
\hline$I_{N S T H O L D}{ }_{i, t-1}$ & $\begin{array}{l}-0.074 \\
(-2.698 * * *)\end{array}$ & & & & & \\
\hline$E Q T H O L D_{i, t-1}$ & & $\begin{array}{l}-0.056 \\
(-1.410)\end{array}$ & & & & \\
\hline$S U M D I S H R_{i, t-1}$ & & & $\begin{array}{l}-0.228 \\
(-0.184)\end{array}$ & & & \\
\hline$S U M C I S H R_{i, t-1}$ & & & & $\begin{array}{l}0.382 \\
(0.152)\end{array}$ & & \\
\hline$S U M D A S H R_{i, t-1}$ & & & & & $\begin{array}{l}-0.500 \\
(-0.279)\end{array}$ & \\
\hline$S_{U M C A S H R} R_{i, t-1}$ & & & & & & $\begin{array}{l}-0.450 \\
\left(-2.378^{* *}\right)\end{array}$ \\
\hline$I N V M I L L S_{i t}$ & $\begin{array}{l}-0.825 \\
(-9.059 * * *)\end{array}$ & $\begin{array}{l}-0.820 \\
(-7.38 * * *)\end{array}$ & $\begin{array}{l}-0.696 \\
(-4.589 * * *)\end{array}$ & $\begin{array}{l}-0.694 \\
(-4.587 * * *)\end{array}$ & $\begin{array}{l}-0.696 \\
(-4.612 * * *)\end{array}$ & $\begin{array}{l}-0.721 \\
(-4.739 * * *)\end{array}$ \\
\hline MKTSH $_{i t-1}$ & $\begin{array}{l}10.240 \\
\left(5.435^{* * *}\right)\end{array}$ & $\begin{array}{l}12.415 \\
(6.114 * * *)\end{array}$ & $\begin{array}{l}11.824 \\
\left(5.806^{* * *}\right)\end{array}$ & $\begin{array}{l}11.838 \\
(5.821 * * *)\end{array}$ & $\begin{array}{l}11.822 \\
\left(5.810^{* * *}\right)\end{array}$ & $\begin{array}{l}10.777 \\
(5.289 * * *)\end{array}$ \\
\hline$Z_{S C O R E_{i t-1}}$ & $\begin{array}{l}-0.000 \\
\left(-1.823^{*}\right)\end{array}$ & $\begin{array}{l}-0.002 \\
\left(-3.266^{* * *}\right)\end{array}$ & $\begin{array}{l}-0.004 \\
(-2.047 * *)\end{array}$ & $\begin{array}{l}-0.004 \\
(-2.047 * *)\end{array}$ & $\begin{array}{l}-0.004 \\
\left(-2.048^{* *}\right)\end{array}$ & $\begin{array}{l}-0.004 \\
(-2.052 * *)\end{array}$ \\
\hline$T A X_{i t-1}$ & $\begin{array}{l}0.493 \\
(3.684 * * *)\end{array}$ & $\begin{array}{l}0.425 \\
(2.642 * * *)\end{array}$ & $\begin{array}{l}0.594 \\
(3.472 * * *)\end{array}$ & $\begin{array}{l}0.591 \\
(3.454 * * *)\end{array}$ & $\begin{array}{l}0.595 \\
(3.474 * * *)\end{array}$ & $\begin{array}{l}0.663 \\
(3.809 * * *)\end{array}$ \\
\hline$A_{U D I T O R_{i t-I}}$ & $\begin{array}{l}-0.054 \\
(-1.535)\end{array}$ & $\begin{array}{l}-0.025 \\
(-0.546)\end{array}$ & $\begin{array}{l}-0.012 \\
(-0.240)\end{array}$ & $\begin{array}{l}-0.013 \\
(-0.249)\end{array}$ & $\begin{array}{l}-0.012 \\
(-0.237)\end{array}$ & $\begin{array}{l}-0.001 \\
(-0.028)\end{array}$ \\
\hline$N O A_{i t-1}$ & $\begin{array}{l}0.000 \\
\left(1.748^{*}\right)\end{array}$ & $\begin{array}{l}0.000 \\
\left(1.893^{*}\right)\end{array}$ & $\begin{array}{l}0.000 \\
\left(1.670^{*}\right)\end{array}$ & $\begin{array}{l}0.000 \\
\left(1.678^{*}\right)\end{array}$ & $\begin{array}{l}0.000 \\
\left(1.674^{*}\right)\end{array}$ & $\begin{array}{l}0.000 \\
\left(1.738^{*}\right)\end{array}$ \\
\hline OPERCYCLE $E_{i t-1}$ & $\begin{array}{l}0.000 \\
(1.426)\end{array}$ & $\begin{array}{l}0.000 \\
(0.934)\end{array}$ & $\begin{array}{l}0.000 \\
(0.524)\end{array}$ & $\begin{array}{l}0.000 \\
(0.519)\end{array}$ & $\begin{array}{l}0.000 \\
(0.521)\end{array}$ & $\begin{array}{l}0.000 \\
(0.497)\end{array}$ \\
\hline$L N M K C A P_{i t}$ & $\begin{array}{l}-0.097 \\
(-12.60 * * *)\end{array}$ & $\begin{array}{l}-0.109 \\
(-11.37 * * *)\end{array}$ & $\begin{array}{l}-0.109 \\
(-10.03 * * *)\end{array}$ & $\begin{array}{l}-0.110 \\
(-9.947 * * *)\end{array}$ & $\begin{array}{l}-0.109 \\
(-10.19 * * *)\end{array}$ & $\begin{array}{l}-0.107 \\
\left(-9.956^{* * *}\right)\end{array}$ \\
\hline$D E B T_{i t}$ & $\begin{array}{l}-0.007 \\
(-1.377)\end{array}$ & $\begin{array}{l}-0.071 \\
\left(-3.306^{* * *}\right)\end{array}$ & $\begin{array}{l}0.040 \\
(0.960)\end{array}$ & $\begin{array}{l}0.039 \\
(0.943)\end{array}$ & $\begin{array}{l}0.039 \\
(0.948)\end{array}$ & $\begin{array}{l}0.035 \\
(0.852)\end{array}$ \\
\hline$M K B K_{i t}$ & $\begin{array}{l}-0.000 \\
(-0.715)\end{array}$ & $\begin{array}{l}-0.000 \\
(-0.341)\end{array}$ & $\begin{array}{l}0.000 \\
(0.257)\end{array}$ & $\begin{array}{l}0.000 \\
(0.257)\end{array}$ & $\begin{array}{l}0.000 \\
(0.257)\end{array}$ & $\begin{array}{l}0.000 \\
(0.266)\end{array}$ \\
\hline$R O A_{i t}$ & $\begin{array}{l}0.070 \\
\left(4.705^{* * *}\right)\end{array}$ & $\begin{array}{l}0.025 \\
(1.024)\end{array}$ & $\begin{array}{l}0.022 \\
(0.713)\end{array}$ & $\begin{array}{l}0.022 \\
(0.731)\end{array}$ & $\begin{array}{l}0.022 \\
(0.725)\end{array}$ & $\begin{array}{l}0.020 \\
(0.671)\end{array}$ \\
\hline F-statistics & $10.550 * * *$ & $9.329 * * *$ & $8.100 * * *$ & $8.069 * * *$ & $8.029 * * *$ & $8.277 * * *$ \\
\hline Adj. R-squared & 0.029 & 0.032 & 0.032 & 0.032 & 0.032 & 0.032 \\
\hline $\begin{array}{l}\text { Year fixed effect } \\
\text { Sector fixed }\end{array}$ & Yes & Yes & Yes & Yes & Yes & Yes \\
\hline $\begin{array}{l}\text { effect } \\
\text { Clustered std err }\end{array}$ & Yes & Yes & Yes & Yes & Yes & Yes \\
\hline $\begin{array}{l}\text { by firms } \\
\text { Observations }\end{array}$ & $\begin{array}{l}\text { Yes } \\
71,003\end{array}$ & $\begin{array}{l}\text { Yes } \\
46,745\end{array}$ & $\begin{array}{l}\text { Yes } \\
40,307\end{array}$ & $\begin{array}{l}\text { Yes } \\
40,307\end{array}$ & $\begin{array}{l}\text { Yes } \\
40,307\end{array}$ & $\begin{array}{l}\text { Yes } \\
40,307\end{array}$ \\
\hline
\end{tabular}

This table reports the OLS regressions of total real activities manipulation in the non-crisis period (1990-2006). The dependent variable is the level of total real earnings management of firm $i$ in year $t$, which is the sum of abnormal production cost and the abnormal discretionary expenditures. INST captures the various measures of mutual fund involvement in the firm. We employ 6 alternative measures of mutual fund ownership. INSTHOLD is a dummy 
variable representing the presence of a fund owner in the firm ownership structure. EQTHOLD is a dummy variable representing the equity ownership of a mutual fund. SUMDISHR, SUMCISHR, SUMDASHR and SUMCASHR represent the one-year lagged values of the percentages of shares held by Diversified Inactive (DI), Concentrated Inactive (CI), Diversified Active (DA) and Concentrated Active (CA) fund investors, respectively. The choice of the remaining control variables are as per Zang (2012). MKTSH is the ratio of a company's sales to the total sales of all the firms in the same industry based on the Fama-French (1997) 48-sector industry classification; $Z S C O R E_{t}$ is a modified version of Altman's Z-score (Altman 1968, 2000) - a proxy for financial condition. $N O A_{t-1}$ represents net operating assets at the beginning of the year and serves as a proxy for the extent of accrual management in previous periods. $N C Y C L E_{t-1}$ is computed as the days receivable plus the days inventory less the days payable at the beginning of the year; $L N M K C A P_{t}$ represents the natural logarithm of market capitalization; $D E B T_{t}$ is the ratio of long term liabilities-to-market capitalization; and $R O A_{t}$ represents the return on assets. We control for year fixed effects, industry fixed effects and correct the standard errors for the firm-level clustering effects. $* * * * *, *$ indicate significance at $1 \%$ percent, $5 \%$, and $10 \%$ levels, respectively. 


\begin{tabular}{|c|c|c|c|c|c|c|}
\hline Variables & Model 1 & Model 2 & Model 3 & Model 4 & Model 5 & Model 6 \\
\hline Constant & $\begin{array}{l}0.358 \\
(3.032 * * *)\end{array}$ & $\begin{array}{l}1.031 \\
(6.338 * * *)\end{array}$ & $\begin{array}{l}0.854 \\
(4.851 * * *)\end{array}$ & $\begin{array}{l}0.832 \\
(4.743 * * *)\end{array}$ & $\begin{array}{l}0.847 \\
(4.823 * * *)\end{array}$ & $\begin{array}{l}0.884 \\
(4.869 * * *)\end{array}$ \\
\hline$I_{N S T H O L D_{i, t-1}}$ & $\begin{array}{l}-0.038 \\
(-0.815)\end{array}$ & & & & & \\
\hline$E Q T H O L D_{i, t-1}$ & & $\begin{array}{l}-0.166 \\
(-2.054 * *)\end{array}$ & & & & \\
\hline$S_{U M D I S H R} R_{i, t-1}$ & & & $\begin{array}{l}-3.286 \\
(-2.134 * *)\end{array}$ & & & \\
\hline$S_{U M C I S H R} R_{i, t-1}$ & & & & $\begin{array}{l}-3.285 \\
(-1.577)\end{array}$ & & \\
\hline$S U M D A S H R_{i, t-1}$ & & & & & $\begin{array}{l}-5.787 \\
\left(-1.668^{*}\right)\end{array}$ & \\
\hline$S_{U M C A S H R}{ }_{i, t-1}$ & & & & & & $\begin{array}{l}-0.440 \\
\left(-1.721^{*}\right)\end{array}$ \\
\hline$I N V M I L L S_{i t}$ & $\begin{array}{l}-0.339 \\
(-2.905 * * *)\end{array}$ & $\begin{array}{l}-1.222 \\
(-6.603 * * *)\end{array}$ & $\begin{array}{l}-1.137 \\
(-4.092 * * *)\end{array}$ & $\begin{array}{l}-1.106 \\
(-4.012 * * *)\end{array}$ & $\begin{array}{l}-1.102 \\
(-3.996 * * *)\end{array}$ & $\begin{array}{l}-1.137 \\
(-4.030 * * *)\end{array}$ \\
\hline MKTSH $_{i t-I}$ & $\begin{array}{l}11.354 \\
(5.721 * * *)\end{array}$ & $\begin{array}{l}11.294 \\
\left(5.320^{* * *}\right)\end{array}$ & $\begin{array}{l}10.954 \\
(4.909 * * *)\end{array}$ & $\begin{array}{l}11.337 \\
(5.079 * * *)\end{array}$ & $\begin{array}{l}11.221 \\
\left(5.150^{* * *}\right)\end{array}$ & $\begin{array}{l}10.522 \\
(4.855 * * *)\end{array}$ \\
\hline$Z_{S C O R E_{i t-1}}$ & $\begin{array}{l}0.000 \\
(0.058)\end{array}$ & $\begin{array}{l}-0.000 \\
(-0.210)\end{array}$ & $\begin{array}{l}-0.002 \\
(-0.529)\end{array}$ & $\begin{array}{l}-0.002 \\
(-0.529)\end{array}$ & $\begin{array}{l}-0.002 \\
(-0.512)\end{array}$ & $\begin{array}{l}-0.001 \\
(-0.457)\end{array}$ \\
\hline$T A X_{i t-I}$ & $\begin{array}{l}1.259 \\
(5.799 * * *)\end{array}$ & $\begin{array}{l}1.053 \\
(4.651 * * *)\end{array}$ & $\begin{array}{l}1.098 \\
(4.650 * * *)\end{array}$ & $\begin{array}{l}1.089 \\
(4.609 * * *)\end{array}$ & $\begin{array}{l}1.070 \\
(4.550 * * *)\end{array}$ & $\begin{array}{l}1.138 \\
(4.801 * * *)\end{array}$ \\
\hline AUDITOR $_{\text {it }-1}$ & $\begin{array}{l}0.001 \\
(0.026)\end{array}$ & $\begin{array}{l}-0.073 \\
(-1.231)\end{array}$ & $\begin{array}{l}-0.098 \\
(-1.560)\end{array}$ & $\begin{array}{l}-0.104 \\
\left(-1.653^{*}\right)\end{array}$ & $\begin{array}{l}-0.104 \\
\left(-1.662^{*}\right)\end{array}$ & $\begin{array}{l}-0.093 \\
(-1.497)\end{array}$ \\
\hline$N O A_{i t-1}$ & $\begin{array}{l}0.000 \\
(1.019)\end{array}$ & $\begin{array}{l}0.000 \\
(0.469)\end{array}$ & $\begin{array}{l}0.000 \\
\left(6.166^{* * *}\right)\end{array}$ & $\begin{array}{l}0.000 \\
(6.223 * * *)\end{array}$ & $\begin{array}{l}0.000 \\
(6.289 * * *)\end{array}$ & $\begin{array}{l}0.000 \\
(5.912 * * *)\end{array}$ \\
\hline OPERCYCLE $E_{i t-I}$ & $\begin{array}{l}0.000 \\
(1.254)\end{array}$ & $\begin{array}{l}-0.000 \\
(-0.260)\end{array}$ & $\begin{array}{l}0.000 \\
\left(1.786^{*}\right)\end{array}$ & $\begin{array}{l}0.000 \\
\left(1.760^{*}\right)\end{array}$ & $\begin{array}{l}0.000 \\
(1.752 *)\end{array}$ & $\begin{array}{l}0.000 \\
\left(1.757^{*}\right)\end{array}$ \\
\hline$L N M K C A P_{i t}$ & $\begin{array}{l}-0.099 \\
\left(-8.396^{* * *}\right)\end{array}$ & $\begin{array}{l}-0.120 \\
(-8.794 * * *)\end{array}$ & $\begin{array}{l}-0.104 \\
(-6.909 * * *)\end{array}$ & $\begin{array}{l}-0.105 \\
\left(-6.836^{* * *}\right)\end{array}$ & $\begin{array}{l}-0.110 \\
(-7.367 * * *)\end{array}$ & $\begin{array}{l}-0.111 \\
(-7.401 * * *)\end{array}$ \\
\hline$D E B T_{i t}$ & $\begin{array}{l}0.000 \\
(0.437)\end{array}$ & $\begin{array}{l}-0.002 \\
(-1.353)\end{array}$ & $\begin{array}{l}-0.043 \\
(-0.495)\end{array}$ & $\begin{array}{l}-0.043 \\
(-0.490)\end{array}$ & $\begin{array}{l}-0.047 \\
(-0.536)\end{array}$ & $\begin{array}{l}-0.052 \\
(-0.591)\end{array}$ \\
\hline$M K B K_{i t}$ & $\begin{array}{l}-0.000 \\
(-0.614)\end{array}$ & $\begin{array}{l}-0.000 \\
(-0.043)\end{array}$ & $\begin{array}{l}0.000 \\
(0.617)\end{array}$ & $\begin{array}{l}0.000 \\
(0.622)\end{array}$ & $\begin{array}{l}0.000 \\
(0.617)\end{array}$ & $\begin{array}{l}0.000 \\
(0.612)\end{array}$ \\
\hline$R O A_{\text {it }}$ & $\begin{array}{l}0.185 \\
(7.213 * * *)\end{array}$ & $\begin{array}{l}0.134 \\
(3.157 * * *)\end{array}$ & $\begin{array}{l}-0.003 \\
(-0.037)\end{array}$ & $\begin{array}{l}-0.000 \\
(-0.001)\end{array}$ & $\begin{array}{l}0.002 \\
(0.021)\end{array}$ & $\begin{array}{l}-0.002 \\
(-0.020)\end{array}$ \\
\hline F-statistics & $10.130 * * *$ & $17.170 * * *$ & $11.640 * * *$ & $11.440 * * *$ & $11.520 * * *$ & $10.920 * * *$ \\
\hline Adj. R-squared & 0.048 & 0.048 & 0.036 & 0.035 & 0.035 & 0.035 \\
\hline $\begin{array}{l}\text { Year fixed effect } \\
\text { Sector fixed }\end{array}$ & Yes & Yes & Yes & Yes & Yes & Yes \\
\hline $\begin{array}{l}\text { effect } \\
\text { Clustered std err }\end{array}$ & Yes & Yes & Yes & Yes & Yes & Yes \\
\hline by firms & Yes & Yes & Yes & Yes & Yes & Yes \\
\hline Observations & 12,321 & 9,126 & 8,118 & 8,118 & 8,118 & 8,118 \\
\hline
\end{tabular}

This table reports the OLS regressions of total real activities manipulation in the crisis period (2007-2009). The dependent variable is the level of total real earnings management of firm $i$ in year $t$, which is the sum of abnormal production cost and the abnormal discretionary expenditures. INST captures the various measures of mutual fund involvement in the firm. We employ 6 alternative measures of mutual fund ownership. INSTHOLD is a dummy 
variable representing the presence of a fund owner in the firm ownership structure. EQTHOLD is a dummy variable representing the equity ownership of a mutual fund. SUMDISHR, SUMCISHR, SUMDASHR and SUMCASHR represent the one-year lagged values of the percentages of shares held by Diversified Inactive (DI), Concentrated Inactive (CI), Diversified Active (DA) and Concentrated Active (CA) fund investors, respectively. The choice of the remaining control variables are as per Zang (2012). MKTSH is the ratio of a company's sales to the total sales of all the firms in the same industry based on the Fama-French (1997) 48-sector industry classification; $Z S C O R E_{t}$ is a modified version of Altman's Z-score (Altman 1968, 2000) - a proxy for financial condition. $N O A_{t-1}$ represents net operating assets at the beginning of the year and serves as a proxy for the extent of accrual management in previous periods. $N C Y C L E_{t-1}$ is computed as the days receivable plus the days inventory less the days payable at the beginning of the year; $L N M K C A P_{t}$ represents the natural logarithm of market capitalization; $D E B T_{t}$ is the ratio of long term liabilities-to-market capitalization; and $R O A_{t}$ represents the return on assets. We control for year fixed effects, industry fixed effects and correct the standard errors for the firm-level clustering effects. ***, **, and * indicate significance at $1 \%$ percent, $5 \%$, and $10 \%$ levels, respectively. 
Table 8 - OLS Regressions of Discretionary Accruals on Institutional Ownership

\begin{tabular}{|c|c|c|c|c|c|c|}
\hline Variables & Model 1 & Model 2 & Model 3 & Model 4 & Model 5 & Model 6 \\
\hline Constant & $\begin{array}{l}-0.026 \\
(-0.841)\end{array}$ & $\begin{array}{l}0.070 \\
(1.298)\end{array}$ & $\begin{array}{l}-0.068 \\
(-1.005)\end{array}$ & $\begin{array}{l}-0.086 \\
(-1.263)\end{array}$ & $\begin{array}{l}-0.063 \\
(-0.936)\end{array}$ & $\begin{array}{l}-0.064 \\
(-0.949)\end{array}$ \\
\hline INSTHOLD $_{i, t-l}$ & $\begin{array}{l}0.028 \\
(2.446 * *)\end{array}$ & & & & & \\
\hline$E Q T H O L D_{i, t-1}$ & & $\begin{array}{l}0.029 \\
(1.632)\end{array}$ & & & & \\
\hline$S U M D I S H R_{i, t-I}$ & & & $\begin{array}{l}-2.200 \\
(-4.867 * * *)\end{array}$ & & & \\
\hline$S U M C I S H R_{i, t-1}$ & & & & $\begin{array}{l}-3.594 \\
(-4.729 * * *)\end{array}$ & & \\
\hline$S U M D A S H R_{i, t-1}$ & & & & & $\begin{array}{l}0.793 \\
(1.013)\end{array}$ & \\
\hline$S U M C A S H R_{i, t-1}$ & & & & & & $\begin{array}{l}-0.328 \\
(-4.162 * * *)\end{array}$ \\
\hline$U N E X P R M_{i t}$ & $\begin{array}{l}-0.012 \\
(-2.641 * * *)\end{array}$ & $\begin{array}{l}-0.014 \\
(-2.418 * *)\end{array}$ & $\begin{array}{l}-0.019 \\
(-2.811 * * *)\end{array}$ & $\begin{array}{l}-0.019 \\
(-2.852 * * *)\end{array}$ & $\begin{array}{l}-0.019 \\
(-2.892 * * *)\end{array}$ & $\begin{array}{l}-0.018 \\
(-2.779 * * *)\end{array}$ \\
\hline$I N V M I L L S_{i t}$ & $\begin{array}{l}-0.089 \\
(-3.375 * * *)\end{array}$ & $\begin{array}{l}-0.061 \\
(-1.053)\end{array}$ & $\begin{array}{l}0.196 \\
(2.797 * * *)\end{array}$ & $\begin{array}{l}0.209 \\
(2.986 * * *)\end{array}$ & $\begin{array}{l}0.219 \\
(3.139 * * *)\end{array}$ & $\begin{array}{l}0.194 \\
(2.764 * * *)\end{array}$ \\
\hline$M K T S H_{i t-1}$ & $\begin{array}{l}4.316 \\
(4.944 * * *)\end{array}$ & $\begin{array}{l}4.692 \\
(4.844 * * *)\end{array}$ & $\begin{array}{l}5.187 \\
(4.877 * * *)\end{array}$ & $\begin{array}{l}5.328 \\
(5.032 * * *)\end{array}$ & $\begin{array}{l}5.414 \\
\left(5.115^{* * *}\right)\end{array}$ & $\begin{array}{l}4.600 \\
(4.398 * * *)\end{array}$ \\
\hline ZSCORE $E_{i t-I}$ & $\begin{array}{l}-0.000 \\
(-3.809 * * *)\end{array}$ & $\begin{array}{l}-0.000 \\
(-2.678 * * *)\end{array}$ & $\begin{array}{l}-0.002 \\
(-3.041 * * *)\end{array}$ & $\begin{array}{l}-0.002 \\
(-3.040 * * *)\end{array}$ & $\begin{array}{l}-0.002 \\
(-3.034 * * *)\end{array}$ & $\begin{array}{l}-0.002 \\
(-3.049 * * *)\end{array}$ \\
\hline$T A X_{i t-1}$ & $\begin{array}{l}1.336 \\
(23.026 * * *)\end{array}$ & $\begin{array}{l}1.081 \\
(15.063 * * *)\end{array}$ & $\begin{array}{l}1.088 \\
(11.915 * * *)\end{array}$ & $\begin{array}{l}1.093 \\
(11.938 * * *)\end{array}$ & $\begin{array}{l}1.071 \\
(11.716 * * *)\end{array}$ & $\begin{array}{l}1.126 \\
(12.276 * * *)\end{array}$ \\
\hline$A U D I T O R_{i t-1}$ & $\begin{array}{l}-0.042 \\
(-3.080 * * *)\end{array}$ & $\begin{array}{l}-0.052 \\
(-3.142 * * *)\end{array}$ & $\begin{array}{l}-0.060 \\
(-3.283 * * *)\end{array}$ & $\begin{array}{l}-0.057 \\
(-3.114 * * *)\end{array}$ & $\begin{array}{l}-0.063 \\
(-3.414 * * *)\end{array}$ & $\begin{array}{l}-0.054 \\
(-2.897 * * *)\end{array}$ \\
\hline$N O A_{i t-1}$ & $\begin{array}{l}-0.000 \\
\left(-1.944^{*}\right)\end{array}$ & $\begin{array}{l}-0.000 \\
(-1.454)\end{array}$ & $\begin{array}{l}-0.000 \\
(-0.945)\end{array}$ & $\begin{array}{l}-0.000 \\
(-0.943)\end{array}$ & $\begin{array}{l}-0.000 \\
(-0.887)\end{array}$ & $\begin{array}{l}-0.000 \\
(-0.877)\end{array}$ \\
\hline OPERCYCLE $E_{i t-1}$ & $\begin{array}{l}0.000 \\
(0.785)\end{array}$ & $\begin{array}{l}-0.000 \\
(-1.333)\end{array}$ & $\begin{array}{l}0.000 \\
(0.813)\end{array}$ & $\begin{array}{l}0.000 \\
(0.816)\end{array}$ & $\begin{array}{l}0.000 \\
(0.787)\end{array}$ & $\begin{array}{l}0.000 \\
(0.765)\end{array}$ \\
\hline$L N M K C A P_{i t}$ & $\begin{array}{l}-0.042 \\
(-13.493 * * *)\end{array}$ & $\begin{array}{l}-0.047 \\
(-11.791 * * *)\end{array}$ & $\begin{array}{l}-0.041 \\
(-9.022 * * *)\end{array}$ & $\begin{array}{l}-0.042 \\
(-9.391 * * *)\end{array}$ & $\begin{array}{l}-0.047 \\
(-10.757 * * *)\end{array}$ & $\begin{array}{l}-0.046 \\
(-10.461 * * *)\end{array}$ \\
\hline$D E B T_{i t}$ & $\begin{array}{l}-0.000 \\
(-2.760 * * *)\end{array}$ & $\begin{array}{l}0.002 \\
(1.381)\end{array}$ & $\begin{array}{l}0.062 \\
(1.670 *)\end{array}$ & $\begin{array}{l}0.062 \\
(1.664 *)\end{array}$ & $\begin{array}{l}0.059 \\
(1.576)\end{array}$ & $\begin{array}{l}0.056 \\
(1.475)\end{array}$ \\
\hline$M K B K_{i t}$ & $\begin{array}{l}0.000 \\
(1.220)\end{array}$ & $\begin{array}{l}0.000 \\
\left(3.045^{* * *}\right)\end{array}$ & $\begin{array}{l}0.000 \\
\left(3.466^{* * *}\right)\end{array}$ & $\begin{array}{l}0.000 \\
(3.473 * * *)\end{array}$ & $\begin{array}{l}0.000 \\
(3.451 * * *)\end{array}$ & $\begin{array}{l}0.000 \\
(3.480 * * *)\end{array}$ \\
\hline$R O A_{i t}$ & $\begin{array}{l}0.315 \\
\left(21.366^{* * *}\right)\end{array}$ & $\begin{array}{l}0.438 \\
(12.383 * * *)\end{array}$ & $\begin{array}{l}0.558 \\
(8.930 * * *)\end{array}$ & $\begin{array}{l}0.559 \\
(8.934 * * *)\end{array}$ & $\begin{array}{l}0.561 \\
(8.938 * * *)\end{array}$ & $\begin{array}{l}0.560 \\
(8.928 * * *)\end{array}$ \\
\hline F-statistics & $55.11 * * *$ & $33.20 * * *$ & $27.91 * * *$ & $27.51 * * *$ & $26.54 * * *$ & $27.55 * * *$ \\
\hline Adj. R-squared & 0.136 & 0.115 & 0.0952 & 0.0950 & 0.0942 & 0.0950 \\
\hline Year fixed effect & Yes & Yes & Yes & Yes & Yes & Yes \\
\hline $\begin{array}{l}\text { Sector fixed effect } \\
\text { Clustered std err }\end{array}$ & Yes & Yes & Yes & Yes & Yes & Yes \\
\hline by firms & Yes & Yes & Yes & Yes & Yes & Yes \\
\hline Observations & 83,324 & 55,871 & 48,425 & 48,425 & 48,425 & 48,425 \\
\hline
\end{tabular}

This table reports the OLS regressions of accruals-based earnings management (AM). The dependent variable is the level of accruals-based earnings management of firm $i$ in year $t$. INST captures the various measures of mutual fund involvement in the firm. We employ 6 alternative measures of mutual fund ownership. INSTHOLD is a dummy variable representing the presence of a fund owner in the firm ownership structure. EQTHOLD is a dummy variable representing the equity ownership of a mutual fund. SUMDISHR, SUMCISHR, SUMDASHR and SUMCASHR represent the one-year lagged values of the percentages of shares held by Diversified Inactive (DI), Concentrated Inactive (CI), Diversified Active (DA) and Concentrated Active (CA) fund investors, respectively. The choice of the remaining control variables are as per Zang (2012). UNEXPRM is the unexpected total real earnings management obtained as the residuals from Models 1 through 6, correspondingly, in Table 6. INVMILLS is the inverse Mills 
ratio calculated from the predicted probability of the firm being invested by mutual funds from Model 4 of Table 5 . MKTSH is the ratio of a company's sales to the total sales of all the firms in the same industry based on the FamaFrench (1997) 48-sector industry classification; $Z S C O R E_{t}$ is a modified version of Altman's Z-score (Altman 1968, 2000) - a proxy for financial condition. $N O A_{t-1}$ represents net operating assets at the beginning of the year and serves as a proxy for the extent of accrual management in previous periods. $N C Y C L E_{t-1}$ is computed as the days receivable plus the days inventory less the days payable at the beginning of the year; $L N M K C A P_{t}$ represents the natural logarithm of market capitalization; $D E B T_{t}$ is the ratio of long term liabilities-to-market capitalization; and $R O A_{t}$ represents the return on assets. We control for year fixed effects, industry fixed effects and correct the standard errors for the firm-level clustering effects. $* * *, * *$, and $*$ indicate significance at $1 \%$ percent, $5 \%$, and $10 \%$ levels, respectively. 
Table 9A - OLS Regressions of Discretionary Accruals on Institutional Ownership in the Non-crisis Period

\begin{tabular}{|c|c|c|c|c|c|c|}
\hline Variables & Model 1 & Model 2 & Model 3 & Model 4 & Model 5 & Model 6 \\
\hline Constant & $\begin{array}{l}-0.031 \\
(-0.745)\end{array}$ & $\begin{array}{l}0.063 \\
(1.071)\end{array}$ & $\begin{array}{l}-0.055 \\
(-0.731)\end{array}$ & $\begin{array}{l}-0.072 \\
(-0.943)\end{array}$ & $\begin{array}{l}-0.055 \\
(-0.720)\end{array}$ & $\begin{array}{l}-0.052 \\
(-0.690)\end{array}$ \\
\hline INSTHOLD $_{i, t-1}$ & $\begin{array}{l}0.028 \\
(2.396 * *)\end{array}$ & & & & & \\
\hline$E Q T H O L D_{i, t-1}$ & & $\begin{array}{l}0.033 \\
(1.728 *)\end{array}$ & & & & \\
\hline$S U M D I S H R_{i, t-1}$ & & & $\begin{array}{l}-2.002 \\
(-3.886 * * *)\end{array}$ & & & \\
\hline$S U M C I S H R_{i, t-1}$ & & & & $\begin{array}{l}-3.937 \\
(-3.624 * * *)\end{array}$ & & \\
\hline$S U M D A S H R_{i, t-1}$ & & & & & $\begin{array}{l}1.373 \\
(1.607)\end{array}$ & \\
\hline$S U M C A S H R_{i, t-1}$ & & & & & & $\begin{array}{l}-0.334 \\
(-3.851 * * *)\end{array}$ \\
\hline$U N E X P R M_{i t}$ & $\begin{array}{l}-0.009 \\
\left(-1.894^{*}\right)\end{array}$ & $\begin{array}{l}-0.010 \\
(-1.551)\end{array}$ & $\begin{array}{l}-0.017 \\
(-2.398 * *)\end{array}$ & $\begin{array}{l}-0.017 \\
(-2.427 * *)\end{array}$ & $\begin{array}{l}-0.017 \\
(-2.452 * *)\end{array}$ & $\begin{array}{l}-0.017 \\
(-2.345 * *)\end{array}$ \\
\hline$I N V M I L L S_{i t}$ & $\begin{array}{l}-0.107 \\
(-2.754 * * *)\end{array}$ & $\begin{array}{l}-0.087 \\
(-1.417)\end{array}$ & $\begin{array}{l}0.169 \\
(2.233 * *)\end{array}$ & $\begin{array}{l}0.179 \\
(2.368 * *)\end{array}$ & $\begin{array}{l}0.189 \\
(2.504 * *)\end{array}$ & $\begin{array}{l}0.165 \\
(2.171 * *)\end{array}$ \\
\hline$M_{K T S H} H_{i t-1}$ & $\begin{array}{l}4.111 \\
(4.430 * * *)\end{array}$ & $\begin{array}{l}4.482 \\
(4.445 * * *)\end{array}$ & $\begin{array}{l}5.173 \\
(4.598 * * *)\end{array}$ & $\begin{array}{l}5.259 \\
(4.704 * * *)\end{array}$ & $\begin{array}{l}5.323 \\
(4.769 * * *)\end{array}$ & $\begin{array}{l}4.492 \\
(4.070 * * *)\end{array}$ \\
\hline$Z S C O R E_{i t-1}$ & $\begin{array}{l}0.000 \\
(0.186)\end{array}$ & $\begin{array}{l}0.000 \\
(0.503)\end{array}$ & $\begin{array}{l}-0.002 \\
(-3.173 * * *)\end{array}$ & $\begin{array}{l}-0.002 \\
(-3.174 * * *)\end{array}$ & $\begin{array}{l}-0.002 \\
(-3.153 * * *)\end{array}$ & $\begin{array}{l}-0.002 \\
(-3.167 * * *)\end{array}$ \\
\hline$T A X_{i t-1}$ & $\begin{array}{l}1.361 \\
(21.335 * * *)\end{array}$ & $\begin{array}{l}1.085 \\
(13.038 * * *)\end{array}$ & $\begin{array}{l}1.074 \\
(10.131 * * *)\end{array}$ & $\begin{array}{l}1.081 \\
(10.150 * * *)\end{array}$ & $\begin{array}{l}1.057 \\
(9.965 * * *)\end{array}$ & $\begin{array}{l}1.115 \\
(10.460 * * *)\end{array}$ \\
\hline$A_{U D I T O R_{i t-1}}$ & $\begin{array}{l}-0.026 \\
\left(-1.748^{*}\right)\end{array}$ & $\begin{array}{l}-0.026 \\
(-1.389)\end{array}$ & $\begin{array}{l}-0.035 \\
(-1.631)\end{array}$ & $\begin{array}{l}-0.032 \\
(-1.500)\end{array}$ & $\begin{array}{l}-0.036 \\
\left(-1.705^{*}\right)\end{array}$ & $\begin{array}{l}-0.027 \\
(-1.273)\end{array}$ \\
\hline$N O A_{i t-1}$ & $\begin{array}{l}-0.000 \\
\left(-1.764^{*}\right)\end{array}$ & $\begin{array}{l}-0.000 \\
(-0.706)\end{array}$ & $\begin{array}{l}-0.000 \\
(-0.511)\end{array}$ & $\begin{array}{l}-0.000 \\
(-0.513)\end{array}$ & $\begin{array}{l}-0.000 \\
(-0.477)\end{array}$ & $\begin{array}{l}-0.000 \\
(-0.448)\end{array}$ \\
\hline OPERCYCLE $E_{i t-1}$ & $\begin{array}{l}0.000 \\
(2.052 * *)\end{array}$ & $\begin{array}{l}0.000 \\
(0.794)\end{array}$ & $\begin{array}{l}0.000 \\
(0.747)\end{array}$ & $\begin{array}{l}0.000 \\
(0.756)\end{array}$ & $\begin{array}{l}0.000 \\
(0.719)\end{array}$ & $\begin{array}{l}0.000 \\
(0.693)\end{array}$ \\
\hline$L N M K C A P_{i t}$ & $\begin{array}{l}-0.044 \\
(-13.043 * * *)\end{array}$ & $\begin{array}{l}-0.050 \\
(-11.723 * * *)\end{array}$ & $\begin{array}{l}-0.044 \\
(-9.067 * * *)\end{array}$ & $\begin{array}{l}-0.045 \\
(-9.238 * * *)\end{array}$ & $\begin{array}{l}-0.050 \\
(-10.760 * * *)\end{array}$ & $\begin{array}{l}-0.049 \\
(-10.476 * * *)\end{array}$ \\
\hline$D E B T_{i t}$ & $\begin{array}{l}0.009 \\
(2.563 * *)\end{array}$ & $\begin{array}{l}0.023 \\
(0.950)\end{array}$ & $\begin{array}{l}0.061 \\
(1.447)\end{array}$ & $\begin{array}{l}0.061 \\
(1.441)\end{array}$ & $\begin{array}{l}0.058 \\
(1.369)\end{array}$ & $\begin{array}{l}0.055 \\
(1.281)\end{array}$ \\
\hline$M K B K_{i t}$ & $\begin{array}{l}0.000 \\
(1.454)\end{array}$ & $\begin{array}{l}0.000 \\
(3.464 * * *)\end{array}$ & $\begin{array}{l}0.000 \\
(3.947 * * *)\end{array}$ & $\begin{array}{l}0.000 \\
(3.959 * * *)\end{array}$ & $\begin{array}{l}0.000 \\
(3.929 * * *)\end{array}$ & $\begin{array}{l}0.000 \\
(3.979 * * *)\end{array}$ \\
\hline$R O A_{i t}$ & $\begin{array}{l}0.314 \\
(16.377 * * *)\end{array}$ & $\begin{array}{l}0.440 \\
(8.748 * * *)\end{array}$ & $\begin{array}{l}0.539 \\
(7.765 * * *)\end{array}$ & $\begin{array}{l}0.540 \\
(7.765 * * *)\end{array}$ & $\begin{array}{l}0.542 \\
(7.769 * * *)\end{array}$ & $\begin{array}{l}0.541 \\
(7.762 * * *)\end{array}$ \\
\hline F-statistics & $49.770 * * *$ & $28.800 * * *$ & $25.230 * * *$ & $24.780 * * *$ & $24.370 * * *$ & $25.050 * * *$ \\
\hline Adj. R-squared & 0.124 & 0.104 & 0.090 & 0.089 & 0.089 & 0.090 \\
\hline Year fixed effect & Yes & Yes & Yes & Yes & Yes & Yes \\
\hline $\begin{array}{l}\text { Sector fixed effect } \\
\text { Clustered std err }\end{array}$ & Yes & Yes & Yes & Yes & Yes & Yes \\
\hline by firms & Yes & Yes & Yes & Yes & Yes & Yes \\
\hline Observations & 71,003 & 46,745 & 40,307 & 40,307 & 40,307 & 40,307 \\
\hline
\end{tabular}

This table reports the OLS regressions of accruals-based earnings management (AM) in the non-crisis period (19902006). The dependent variable is the level of accruals-based earnings management of firm $i$ in year $t$. INST captures the various measures of mutual fund involvement in the firm. We employ 6 alternative measures of mutual fund ownership. INSTHOLD is a dummy variable representing the presence of a fund owner in the firm ownership structure. EQTHOLD is a dummy variable representing the equity ownership of a mutual fund. SUMDISHR, SUMCISHR, SUMDASHR and SUMCASHR represent the one-year lagged values of the percentages of shares held by Diversified Inactive (DI), Concentrated Inactive (CI), Diversified Active (DA) and Concentrated Active (CA) fund investors, respectively. UNEXPRM is the unexpected total real earnings management obtained as the residuals 
from Models 1 through 6, correspondingly, in Table 6. INVMILLS is the inverse Mills ratio calculated from the predicted probability of the firm being invested by mutual funds from Model 4 of Table 5. The choice of the remaining control variables are as per Zang (2012). MKTSH is the ratio of a company's sales to the total sales of all the firms in the same industry based on the Fama-French (1997) 48-sector industry classification; $Z S C O R E_{t}$ is a modified version of Altman's Z-score (Altman 1968, 2000) - a proxy for financial condition. $N O A_{t-1}$ represents net operating assets at the beginning of the year and serves as a proxy for the extent of accrual management in previous periods. $N C Y C L E_{t-1}$ is computed as the days receivable plus the days inventory less the days payable at the beginning of the year; $L N M K C A P_{t}$ represents the natural logarithm of market capitalization; $D E B T_{t}$ is the ratio of long term liabilities-to-market capitalization; and $R O A_{t}$ represents the return on assets. We control for year fixed effects, industry fixed effects and correct the standard errors for the firm-level clustering effects. ***, **, and * indicate significance at $1 \%$ percent, $5 \%$, and $10 \%$ levels, respectively. 
Table 9B - OLS Regressions of Discretionary Accruals on Institutional Ownership in the Crisis Period

\begin{tabular}{|c|c|c|c|c|c|c|}
\hline Variables & Model 1 & Model 2 & Model 3 & Model 4 & Model 5 & Model 6 \\
\hline Constant & $\begin{array}{l}0.098 \\
(2.694 * * *)\end{array}$ & $\begin{array}{l}0.135 \\
(1.623)\end{array}$ & $\begin{array}{l}0.013 \\
(0.167)\end{array}$ & $\begin{array}{l}-0.009 \\
(-0.113)\end{array}$ & $\begin{array}{l}0.006 \\
(0.077)\end{array}$ & $\begin{array}{l}0.030 \\
(0.381)\end{array}$ \\
\hline INSTHOLD $_{i, t-l}$ & $\begin{array}{l}0.000 \\
(0.020)\end{array}$ & & & & & \\
\hline$E Q T H O L D_{i, t-1}$ & & $\begin{array}{l}-0.006 \\
(-0.148)\end{array}$ & & & & \\
\hline$S U M D I S H R_{i, t-I}$ & & & $\begin{array}{l}-2.477 \\
(-4.099 * * *)\end{array}$ & & & \\
\hline$S_{U M C I S H R}{ }_{i, t-1}$ & & & & $\begin{array}{l}-3.374 \\
(-4.558 * * *)\end{array}$ & & \\
\hline$S U M D A S H R_{i, t-1}$ & & & & & $\begin{array}{l}-4.201 \\
(-2.312 * *)\end{array}$ & \\
\hline$S U M C A S H R_{i, t-1}$ & & & & & & $\begin{array}{l}-0.286 \\
(-2.474 * *)\end{array}$ \\
\hline UNEXPRM $M_{i t}$ & $\begin{array}{l}-0.028 \\
(-3.242 * * *)\end{array}$ & $\begin{array}{l}-0.037 \\
(-3.701 * * *)\end{array}$ & $\begin{array}{l}-0.027 \\
(-2.481 * *)\end{array}$ & $\begin{array}{l}-0.027 \\
(-2.518 * *)\end{array}$ & $\begin{array}{l}-0.028 \\
(-2.568 * *)\end{array}$ & $\begin{array}{l}-0.027 \\
(-2.531 * *)\end{array}$ \\
\hline$I N V M I L L S_{i t}$ & $\begin{array}{l}-0.053 \\
(-2.399 * *)\end{array}$ & $\begin{array}{l}0.001 \\
(0.011)\end{array}$ & $\begin{array}{l}0.348 \\
(2.823 * * *)\end{array}$ & $\begin{array}{l}0.365 \\
(2.966 * * *)\end{array}$ & $\begin{array}{l}0.377 \\
(3.069 * * *)\end{array}$ & $\begin{array}{l}0.356 \\
(2.880 * * *)\end{array}$ \\
\hline$M K T S H_{i t-1}$ & $\begin{array}{l}4.925 \\
(4.466 * * *)\end{array}$ & $\begin{array}{l}4.853 \\
(4.252 * * *)\end{array}$ & $\begin{array}{l}4.714 \\
(3.873 * * *)\end{array}$ & $\begin{array}{l}4.937 \\
(4.054 * * *)\end{array}$ & $\begin{array}{l}4.933 \\
(4.032 * * *)\end{array}$ & $\begin{array}{l}4.501 \\
(3.677 * * *)\end{array}$ \\
\hline ZSCORE $E_{i t-I}$ & $\begin{array}{l}-0.000 \\
(-5.241 * * *)\end{array}$ & $\begin{array}{l}-0.001 \\
(-1.576)\end{array}$ & $\begin{array}{l}-0.012 \\
(-3.330 * * *)\end{array}$ & $\begin{array}{l}-0.012 \\
(-3.340 * * *)\end{array}$ & $\begin{array}{l}-0.012 \\
(-3.308 * * *)\end{array}$ & $\begin{array}{l}-0.011 \\
(-3.268 * * *)\end{array}$ \\
\hline$T A X_{i t-1}$ & $\begin{array}{l}1.185 \\
(11.717 * * *)\end{array}$ & $\begin{array}{l}1.070 \\
(9.875 * * *)\end{array}$ & $\begin{array}{l}1.183 \\
(8.534 * * *)\end{array}$ & $\begin{array}{l}1.184 \\
(8.536 * * *)\end{array}$ & $\begin{array}{l}1.163 \\
(8.398 * * *)\end{array}$ & $\begin{array}{l}1.207 \\
(8.597 * * *)\end{array}$ \\
\hline$A U D I T O R_{i t-1}$ & $\begin{array}{l}-0.125 \\
(-5.230 * * *)\end{array}$ & $\begin{array}{l}-0.165 \\
(-6.075 * * *)\end{array}$ & $\begin{array}{l}-0.158 \\
(-5.488 * * *)\end{array}$ & $\begin{array}{l}-0.161 \\
(-5.596 * * *)\end{array}$ & $\begin{array}{l}-0.163 \\
(-5.636 * * *)\end{array}$ & $\begin{array}{l}-0.156 \\
(-5.362 * * *)\end{array}$ \\
\hline$N O A_{i t-1}$ & $\begin{array}{l}-0.000 \\
(-1.132)\end{array}$ & $\begin{array}{l}-0.000 \\
(-1.462)\end{array}$ & $\begin{array}{l}-0.000 \\
(-2.633 * * *)\end{array}$ & $\begin{array}{l}-0.000 \\
(-2.613 * * *)\end{array}$ & $\begin{array}{l}-0.000 \\
(-2.551 * *)\end{array}$ & $\begin{array}{l}-0.000 \\
(-2.708 * * *)\end{array}$ \\
\hline OPERCYCLE $E_{i t-1}$ & $\begin{array}{l}-0.000 \\
(-4.059 * * *)\end{array}$ & $\begin{array}{l}-0.000 \\
(-6.533 * * *)\end{array}$ & $\begin{array}{l}0.000 \\
(0.953)\end{array}$ & $\begin{array}{l}0.000 \\
(0.934)\end{array}$ & $\begin{array}{l}0.000 \\
(0.917)\end{array}$ & $\begin{array}{l}0.000 \\
(0.932)\end{array}$ \\
\hline$L N M K C A P_{i t}$ & $\begin{array}{l}-0.030 \\
(-5.458 * * *)\end{array}$ & $\begin{array}{l}-0.029 \\
(-4.217 * * *)\end{array}$ & $\begin{array}{l}-0.024 \\
(-2.980 * * *)\end{array}$ & $\begin{array}{l}-0.022 \\
(-2.768 * * *)\end{array}$ & $\begin{array}{l}-0.028 \\
(-3.585 * * *)\end{array}$ & $\begin{array}{l}-0.029 \\
(-3.670 * * *)\end{array}$ \\
\hline$D E B T_{i t}$ & $\begin{array}{l}-0.000 \\
(-3.863 * * *)\end{array}$ & $\begin{array}{l}0.001 \\
(0.337)\end{array}$ & $\begin{array}{l}0.018 \\
(0.435)\end{array}$ & $\begin{array}{l}0.020 \\
(0.467)\end{array}$ & $\begin{array}{l}0.016 \\
(0.374)\end{array}$ & $\begin{array}{l}0.013 \\
(0.301)\end{array}$ \\
\hline$M K B K_{i t}$ & $\begin{array}{l}-0.000 \\
(-1.467)\end{array}$ & $\begin{array}{l}-0.000 \\
(-1.565)\end{array}$ & $\begin{array}{l}-0.000 \\
(-1.136)\end{array}$ & $\begin{array}{l}-0.000 \\
(-1.116)\end{array}$ & $\begin{array}{l}-0.000 \\
(-1.156)\end{array}$ & $\begin{array}{l}-0.000 \\
(-1.192)\end{array}$ \\
\hline$R O A_{i t}$ & $\begin{array}{l}0.371 \\
(19.804 * * *)\end{array}$ & $\begin{array}{l}0.471 \\
(10.643 * * *)\end{array}$ & $\begin{array}{l}0.728 \\
\left(7.326^{* * *}\right)\end{array}$ & $\begin{array}{l}0.729 \\
(7.346 * * *)\end{array}$ & $\begin{array}{l}0.732 \\
(7.344 * * *)\end{array}$ & $\begin{array}{l}0.730 \\
(7.322 * * *)\end{array}$ \\
\hline F-statistics & $38.060 * * *$ & $36.270 * * *$ & $20.960 * * *$ & $21.490 * * *$ & $20.280 * * *$ & $20.350 * * *$ \\
\hline $\begin{array}{l}\text { Adj. R-squared } \\
\text { Year fixed }\end{array}$ & 0.214 & 0.181 & 0.140 & 0.140 & 0.139 & 0.139 \\
\hline $\begin{array}{l}\text { effect } \\
\text { Sector fixed }\end{array}$ & Yes & Yes & Yes & Yes & Yes & Yes \\
\hline $\begin{array}{l}\text { effect } \\
\text { Clustered std }\end{array}$ & Yes & Yes & Yes & Yes & Yes & Yes \\
\hline err by firms & Yes & Yes & Yes & Yes & Yes & Yes \\
\hline Observations & 12,321 & 9,126 & 8,118 & 8,118 & 8,118 & 8,118 \\
\hline
\end{tabular}

This table reports the OLS regressions of accruals-based earnings management (AM) in the crisis period (20072009). The dependent variable is the level of accruals-based earnings management of firm $i$ in year $t$. INST captures the various measures of mutual fund involvement in the firm. We employ 6 alternative measures of mutual fund ownership. INSTHOLD is a dummy variable representing the presence of a fund owner in the firm ownership structure. EQTHOLD is a dummy variable representing the equity ownership of a mutual fund. SUMDISHR, SUMCISHR, SUMDASHR and SUMCASHR represent the one-year lagged values of the percentages of shares held by Diversified Inactive (DI), Concentrated Inactive (CI), Diversified Active (DA) and Concentrated Active (CA) 
fund investors, respectively. UNEXPRM is the unexpected total real earnings management obtained as the residuals from Models 1 through 6, correspondingly, in Table 6. INVMILLS is the inverse Mills ratio calculated from the predicted probability of the firm being invested by mutual funds from Model 4 of Table 5 . The choice of the remaining control variables are as per Zang (2012). MKTSH is the ratio of a company's sales to the total sales of all the firms in the same industry based on the Fama-French (1997) 48-sector industry classification; $Z S C O R E_{t}$ is a modified version of Altman's Z-score (Altman 1968, 2000) - a proxy for financial condition. $N O A_{t-1}$ represents net operating assets at the beginning of the year and serves as a proxy for the extent of accrual management in previous periods. $N C Y C L E_{t-1}$ is computed as the days receivable plus the days inventory less the days payable at the beginning of the year; $L N M K C A P_{t}$ represents the natural logarithm of market capitalization; $D E B T_{t}$ is the ratio of long term liabilities-to-market capitalization; and $R O A_{t}$ represents the return on assets. We control for year fixed effects, industry fixed effects and correct the standard errors for the firm-level clustering effects. ${ }^{* * *}, * *$, and $*$ indicate significance at $1 \%$ percent, $5 \%$, and $10 \%$ levels, respectively. 


\section{Appendix 1}

Regression Analysis to Measure Real activities Manipulation and Accrual-Based Earnings Management

\begin{tabular}{|c|c|c|c|c|c|c|}
\hline \multirow{2}{*}{$\begin{array}{l}\text { Independent } \\
\text { Variables } \\
\text { Intercept }\end{array}$} & \multicolumn{2}{|c|}{$\begin{array}{l}\text { Discretionary Accrual }_{(t)} / \\
\text { Asset }_{(t-1)} \text { (Equation 3) }\end{array}$} & \multicolumn{2}{|c|}{$\begin{array}{l}\text { Production Cost }_{(t)} / \text { Asset }_{(t-1)} \\
\text { Equation 4) }^{\text {Equation }}\end{array}$} & \multicolumn{2}{|c|}{$\begin{array}{l}\text { Discretionary Expense }_{(t)} / \\
\text { Asset }_{(t-1)} \text { (Equation 5) }\end{array}$} \\
\hline & -0.155 & -0.560 & -0.081 & 0.26 & 0.132 & $9.13 * * *$ \\
\hline $1 /$ Asset $_{(t-1)}$ & -0.016 & $-21.98 * * *$ & 0.005 & $16.24 * * *$ & 0.822 & $12.04 * * *$ \\
\hline $\operatorname{Sales}_{(\mathrm{t})} / \operatorname{Asset}_{(\mathrm{t}-1)}$ & & & 0.760 & $139.75 * * *$ & & \\
\hline $\operatorname{Sales}_{(t-1)} / \operatorname{Asset}_{(t-1)}$ & & & & & 0.047 & $12.38 * * *$ \\
\hline$\Delta \operatorname{Sales}_{(\mathrm{t})} / \operatorname{Asset}_{(\mathrm{t}-1)}$ & 0.194 & $15.66^{* * *}$ & 0.007 & $5.85 * * *$ & & \\
\hline$\Delta \operatorname{Sales}_{(\mathrm{t}-1)} / \operatorname{Asset}_{(\mathrm{t}-}$ & & & -0.030 & $-4.15 * * *$ & & \\
\hline $\mathrm{PPE}_{(\mathrm{t})} /$ Asset $_{(\mathrm{t}-1)}$ & -0.102 & $-12.11 * * *$ & & & & \\
\hline $\begin{array}{l}\text { Mean Adj. R- } \\
\text { squared }\end{array}$ & $43.56 \%$ & & $49.23 \%$ & & $43.26 \%$ & \\
\hline $\begin{array}{l}\text { Mean \# of } \\
\text { observations } \\
\text { \# industry-years }\end{array}$ & $\begin{array}{l}115.59 \\
834\end{array}$ & & $\begin{array}{l}119.48 \\
874\end{array}$ & & $\begin{array}{l}119.18 \\
853\end{array}$ & \\
\hline
\end{tabular}

The regressions are estimated cross-sectionally for each industry-year for the period 1990-2009 using the universe of firms in Compustat. The Fama-French 48 industry grouping is used. The reported coefficients are the mean values of the coefficients across industry-years. T-statistics are calculated using the standard errors of the coefficients across industry-years. The adjusted $\mathrm{R}^{2}$ (number of observations) is the mean adjusted $\mathrm{R}^{2}$ (number of observations) across industry-years. ${ }^{*}, *$, and $* *$ represent significance at 10 percent, 5 percent, and 1 percent levels, respectively. 